\title{
Forest restoration following surface mining disturbance: challenges and solutions
}

\author{
S. Ellen Macdonald ${ }^{1} \cdot$ Simon M. Landhäusser $^{1} \cdot$ \\ Jeff Skousen $^{6} \cdot$ Jennifer Franklin $^{2} \cdot$ Jan Frouz $^{3}$. \\ Sarah Hall ${ }^{4} \cdot$ Douglass F. Jacobs $^{5} \cdot$ Sylvie Quideau $^{1}$
}

Received: 11 April 2015/Accepted: 31 July 2015/Published online: 9 August 2015

(C) The Author(s) 2015. This article is published with open access at Springerlink.com

\begin{abstract}
Many forested landscapes around the world are severely altered during mining for their rich mineral and energy reserves. Herein we provide an overview of the challenges inherent in efforts to restore mined landscapes to functioning forest ecosystems and present a synthesis of recent progress using examples from North America, Europe and Australia. We end with recommendations for further elaboration of the Forestry Reclamation Approach emphasizing: (1) Landform reconstruction modelled on natural systems and creation of topographic heterogeneity at a variety of scales; (2) Use and placement of overburden, capping materials and organic amendments to facilitate soil development processes and create a suitable rooting medium for trees; (3) Alignment of landform, topography, overburden, soil and tree species to create a diversity of target ecosystem types; (4) Combining optimization of stock type and planting techniques with early planting of a diversity of tree species; (5) Encouraging natural regeneration as much as possible; (6) Utilizing direct placement of forest floor material combined with seeding of native species to rapidly re-establish native forest understory vegetation; (7) Selective ongoing management to encourage development along the desired successional trajectory.
\end{abstract}

Jennifer Franklin, Jan Frouz, Sarah Hall, Douglass F. Jacobs and Sylvie Quideau have contributed equally to this manuscript.

\section{S. Ellen Macdonald}

ellen.macdonald@ualberta.ca

1 Department of Renewable Resources, University of Alberta, Edmonton, AB T6G2H1, Canada

2 Department of Forestry, Wildlife and Fisheries, University of Tennessee, Knoxville, TN 37996-4563, USA

3 Institute for Environmental Studies, Faculty of Science, Charles University, Benátská 2, Prague 12800, Czech Republic

4 Agriculture and Natural Resources, Berea College, Berea, KY 40404, USA

5 Department of Forestry and Natural Resources, Purdue University, West Lafayette, IN 47907-2061, USA

6 Plant and Soil Sciences, West Virginia University, Morgantown, WV 26506, USA 
Successful restoration of forest ecosystems after severe mining disturbance will be facilitated by a regulatory framework that acknowledges and accepts variation in objectives and outcomes.

Keywords Mining - Forest restoration - Landform reconstruction - Microbial communities - Soil redevelopment - Tree establishment · Forest understory vegetation

\section{Introduction}

A large proportion of the world's mineral and energy resources are found in forested regions, which are consequently subjected to severe disturbance by surface mining. This is a major contributor to the current global need for forest reclamation and restoration (World Resources Institute 2014) and helps explain the increasing interest in forest restoration (Angel et al. 2005; Burton and Macdonald 2011). The broad objective of forest restoration is to return the land to productive capability with an ecosystem comprised of native species and that will function to provide a diversity of economic and ecological values (Grant and Koch 2007; Zipper et al. 2011b). Restoration of forest landscapes after severe mining disturbance presents substantial challenges. For example, the need to re-create the landform complexity that underlies variation in ecosystem structure, composition and function and to redevelop soil types that in natural systems develop slowly over long time periods. Further, forests are structurally complex ecosystems with a diversity of plant species, the dominant ones being very long-lived; thus there is a need to account for long-term successional development of these ecosystems. Finally, there is the need to ensure the resilience of reclaimed ecosystems in the face of future natural and anthropogenic disturbances.

Early efforts to reclaim forested lands after mining disturbance often focused on revegetation with relatively little attention to landform re-creation and the use of native species or re-establishment of tree cover (Grant and Koch 2007; Gorman et al. 2001; Skousen and Zipper 2014; Zeleznik and Skousen 1996). This has changed in recent years, however. For example, the Surface Mining Control and Reclamation Act (SMCRA), enacted in the United States in 1977 caused a major change in reclamation practice by requiring assessment of the characteristics of the potential mined site and an accompanying strategy to restore environmental conditions after mining (Skousen and Zipper 2014; Zipper 2000). The initial focus was on reducing erosion; this led authorities to encourage grading and smoothing of reclaimed land surfaces and rapid establishment of grasses and legumes, often agricultural forages (Chaney et al. 1995; Plass 1982; Torbert and Burger 2000). If these lands were not used for grazing, however, they could naturally revert to woody vegetation, particularly on sites adjacent to forest (Franklin et al. 2012; Skousen et al. 2006). Alternatively, sites would often have compacted soils with chemical properties quite different from native soils; this, plus the dense cover of non-native herbaceous vegetation, inhibited establishment of forest cover for decades (Angel et al. 2005; Zipper et al. 2011a). The Forestry Reclamation Approach (FRA) was developed to address this challenge in the Eastern USA coal region, which is comprised primarily of temperate deciduous forest (Burger et al. 2005a; Zipper et al. 2011b). It described an approach to reclaiming mines to forest vegetation that considered creation of a rooting medium and rough surface, thinking these would be good for tree growth and would encourage re- 
colonization of native species. Further it emphasized using ground cover species that would have fewer negative competitive effects on trees and it promoted good planting techniques with a diversity of tree species. Finally, the FRA focused on setting up conditions to encourage future natural plant community succession.

In Alberta, Canada, the rapidly expanding oil sands mining industry is located in the boreal forest, another rich and diverse forest ecosystem being severely impacted by mineral extraction. Reclamation regulations have changed dramatically over the past five decades (Powter et al. 2012). The Alberta Environmental Protection and Enhancement Act, which currently governs conservation and reclamation of mined lands in Alberta, includes the stated objective to "return the specific land to equivalent land capability" (Government of Alberta 2014). Approvals for oil sands mines require operators to "reclaim the land so that the reclaimed soils and landforms are capable of supporting a self-sustaining, locally common boreal forest....integrated with the surrounding area" (e.g., Alberta Environment Approval \#46586-00-00 Imperial Oil Resources, Kearl Oil Sands Processing Plant and Mine). A number of regulations within mine operating approvals are designed to help meet this objective. For example, there are requirements for salvaging, stockpiling, and replacing soil materials, including all organic matter on the surface of the soil; a particular emphasis of this is the use of upland surface soils. Other supporting guidelines have also been developed including a classification system for determining land capability (Cumulative Environmental Management Association 2006), detailed guidelines for reclamation that focus on recreating a diversity of ecosite types in which landform, soils and vegetation are compatible (Cumulative Environmental Management Association 2009), and a criteria and indicators framework for assessing success (Poscente and Charette 2012).

There is a long tradition of post-mining reclamation in European countries. For example, with the general mining law \#146 of 1854, the Emperor of the Austrian Hungarian Empire established an obligation to return mined landscapes to their original use by reclamation. This law became the basis for mining and reclamation in most successor countries of the Empire. Most European countries now have in place obligations for mining companies to restore mined lands to their original land uses and require that some reclamation planning be undertaken before mining starts. The particular reclamation techniques in Europe are variable; recently some legal regulations recognized the value of near natural processes to restore diversity and protect rare species (Hu 2014). Regulations in other jurisdictions are variable and in some regions there are relatively few regulations in place to ensure restoration of forest ecosystems after severe industrial disturbance.

Objectives for restoration of jarrah forest sites following bauxite mining in Australia include protecting native biodiversity, water catchment protection, timber productivity and rebuilding forest ecosystems that are compatible with values and uses of the surrounding forest landscape (Gardner and Bell 2007; Grant and Koch 2007). Current practices for restoration post-bauxite mining are a product of continuing evolution of practices and regulations, informed by research and driven by intense public scrutiny (Grant and Koch 2007; Koch and Hobbs 2007). The initial practice of planting exotic pines or non-native eucalypts was replaced in the late 1980's by use of only native tree species and reestablishment of native understory vegetation by sowing, planting or direct placement of surface soil materials (Grant and Koch 2007; Norman et al. 2006). At the same time, recontouring fashioned after natural landforms and deep ripping of the mine pit floor were introduced (Gardner and Bell 2007). An understanding of the resilience of unmined forests to natural disturbance underpins restoration practices and guidelines (Grant and Koch 2007). 
Herein we review the current state of knowledge regarding reclamation and restoration of forest ecosystems following surface mining disturbance, explore common challenges, and synthesize the principles that could underlie development of best practices. We draw upon examples from different regions (mainly North America but including some from Europe and Australia) each of which has valuable knowledge to contribute. We conclude by suggesting a further evolution of the Forestry Reclamation Approach (FRA) that can be applied broadly to meet objectives for forest restoration.

\section{Topographic variation from microsite to landscape}

The first important consideration of land reclamation is the reconstruction of the disturbed landform, which is ideally guided by the pre-existing landform and projected post-mining land use. Topographic reconstruction is a critical step in the reclamation process, as the rebuilt landform is the foundation for all following reclamation practices (Toy and Chuse 2005). The challenge of topographic reconstruction is to produce landforms that approximate a state of dynamic equilibrium under prevailing environmental and climatic conditions (Toy and Black 2000) and that meet the objectives for post-mining land uses (Skousen and Zipper 2014). At the landscape scale, consideration should be given to the type and arrangement of landforms along with the placement, stability, hydrological and chemical characteristics of the material types used to construct them (Fig. 1). To develop a functional landscape, ponds, lakes, and streams must be reconstructed and located in such a way as to tie them into the geohydrological setting; this should be similar to natural systems where these components are hydrologically connected at a range of spatial and temporal scales (Fig. 1; Devito et al. 2012).

Rebuilt landscapes need to be in a state of dynamic equilibrium so that they are able to develop and evolve, and can be sustained through effects of climate (e.g. precipitation and storm events), changes in topography (e.g. land consolidation and subsidence), and properties of the geological material types (e.g. hydrological and chemical properties, erosion risk, slope stability) (Devito et al. 2012). Climate cannot be controlled but water availability and redistribution, as well evapotranspiration demand, can be managed through geology, cover soils, and re-established vegetation, including their spatial arrangement and connectivity in the rebuilt landscape. When water is in excess, the design of these landscapes and landforms should allow for the redistribution of water to either storage, to be available during extended dry periods, or to other locations in the landscape. Devito et al. (2012) suggested that the heterogeneity of geological materials and topography should be used to create landforms with ample variation at the meso- and micro-scale, which will in turn influence water storage and movement.

The landscape design is the foundation upon which the cover soils and the subsequent ecosystems are placed. Therefore significant consideration needs to be given to cover material types, their placement and arrangements, and the surface conditions that will influence early ecosystem development as well as future trajectories. Layering and thickness of the surface soil materials as well as meso- and micro-topographic variation are key to the re-establishment and sustainability of forest ecosystems and plant communities (Figs. 1, 2). At these scales, topography and habitat heterogeneity appear to be important variables for the establishment of both plants and associated invertebrate communities (Tropek et al. 2013). Mesotopographical variation (1-10 m scale) increases capture (larger surface area) and longer-term storage of moisture (Toy and Black 2000). Creating 


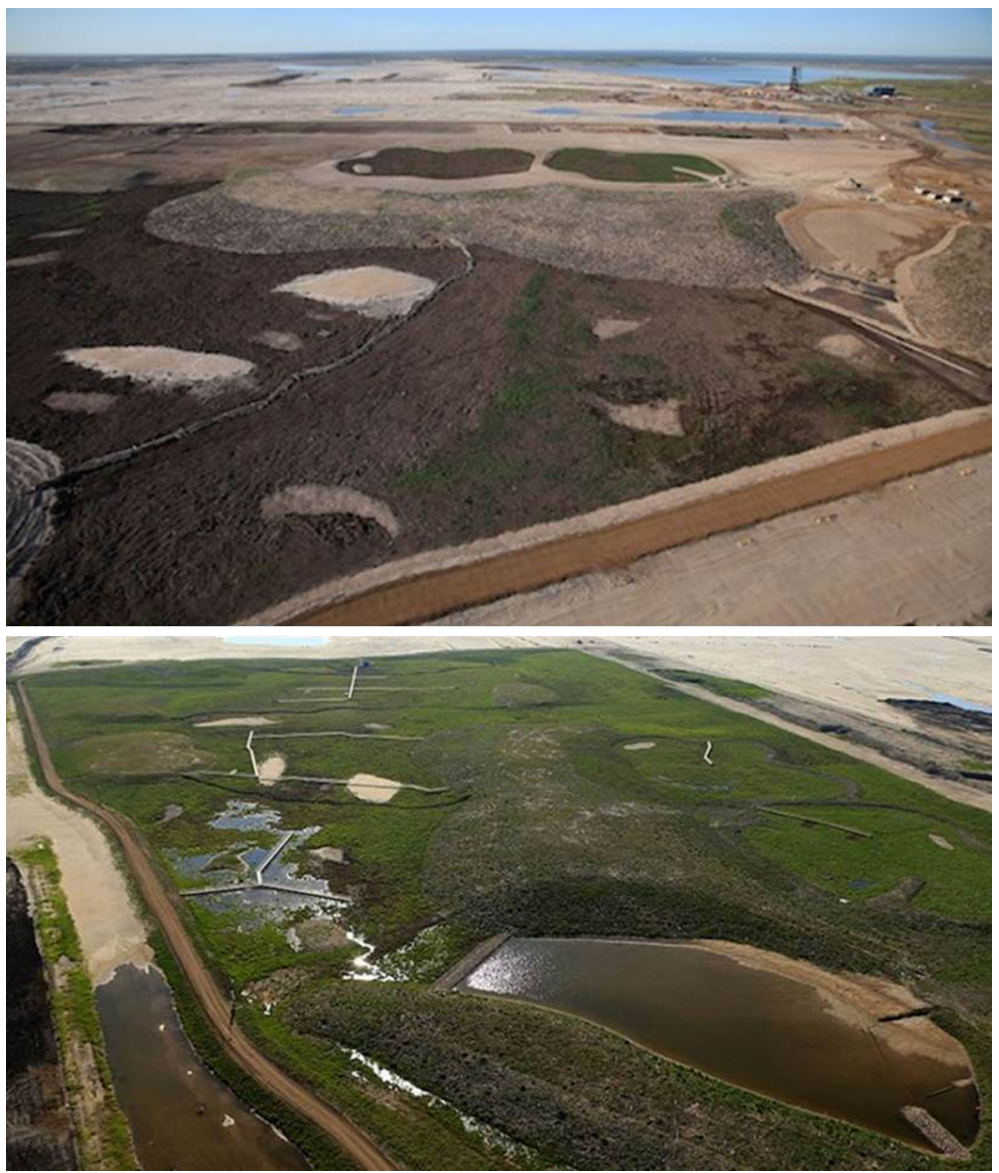

Fig. 1 Landform reconstruction, showing heterogeneity of materials and meso-topography, before (above) and after (below) revegetation after oil sands mining in Alberta, Canada. Photo courtesy of Syncrude Canada Ltd

undulating or hilly surfaces allows for the development of structures such as shallow depressions (swales) designed to collect or potentially redirect water; these can be used to collect and hold water and are most useful in reforestation of degraded, mostly-bare, arid or semi-arid hillsides where water can be directed to trees and vegetation (Toy and Chuse 2005). These structures are most useful when they follow contour lines, as water will otherwise not flow or will flow only over short distances (Tropek et al. 2013).

Layering of cover material types with different textures creates interfaces that can influence moisture availability and field capacity of soils (Zettl et al. 2011). For example downward water movement in layered soil materials can be influenced by capillary barriers that form when unsaturated fine materials overlay unsaturated coarser materials (Miyazaki et al. 1993; Alfnes et al. 2004; Si et al. 2011) or by hydraulic barriers that are due to the presence of a fine, less permeable layer underlying coarser-textured soil (Hillel and Talpaz 1977; Si et al. 2011). Engineered soil covers often include capillary barriers created by the layering of finer textured soil over coarser textured soil (Stormont 1996). The presence of a 


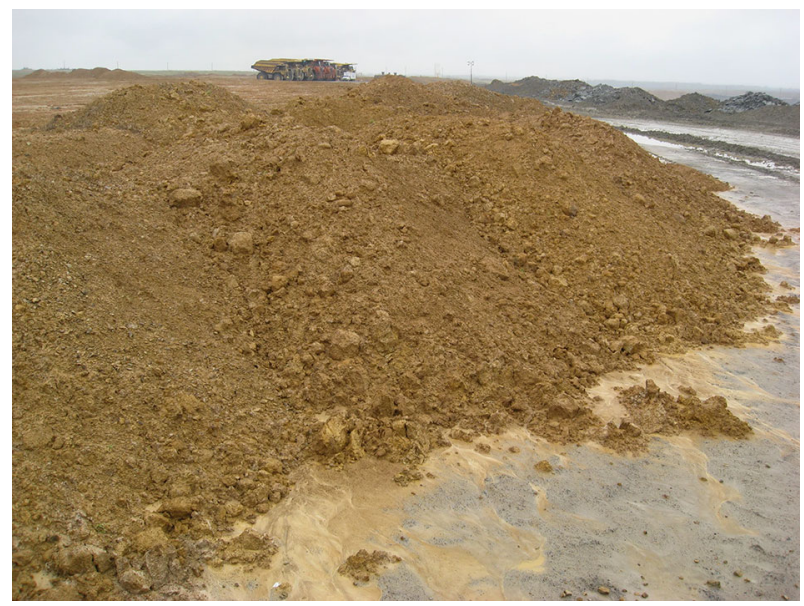

Fig. 2 Soil replacement following coal mining on a reclamation site in southwestern Indiana, USA. Operational procedures in this region call for level grading of the replacement soil followed by planting of native hardwood trees. Photo credit: D.F. Jacobs

capillary barrier can increase the available water holding capacity and thus the water available for plant growth, lateral drainage, and/or percolation (Huang et al. 2013). This in turn will influence plant species composition, root distribution, leaf area development, and overall productivity of reclaimed sites. An important consideration in placing soil materials is to avoid compaction, which can hamper planting, reduce soil air and water holding capacity, and impede root growth (Grant and Koch 2007; Sweigard et al. 2007).

Micro-topographic and soil heterogeneity can be advantageous for mine reclamation (Kappes et al. 2012). Micro-topography has a critical influence on reclamation success and should be aligned with the objectives for post-mining land use, topography, and drainage systems. A rough surface can facilitate natural revegetation and encourage plant species diversity (Groninger et al. 2007; Mackenzie and Naeth 2010; Skousen et al. 2006; Schott et al. 2014). Microtopographical variation increases the range of environmental conditions allowing for a greater variety of species to establish. Surface roughness produces variation in conditions at the $1 \mathrm{~cm}$ to $1 \mathrm{~m}$ spatial scale, in turn creating wide variation in moisture availability and exposure to sun and wind. On reclaimed sites in the boreal forest, smallscale variation and heterogeneity in cover soil materials and their nutrient and carbon status appear to play a role in seedling establishment and early success (Wolken et al. 2010; Pinno et al. 2012, 2014). Surface roughness can be achieved by reduced smoothing and "treading in" of the surfaces during the reconstruction process, or can be artificially increased through the deposition of materials such as woody debris on the surface (Grant and Koch 2007).

Woody debris can be beneficial during reclamation for a variety of reasons. When placed on a mine reclamation site, woody debris can influence soil microbial communities, improve soil nutrient and water holding capacity, and can contribute to development of nutrient cycling (Brown and Naeth 2014; Dimitriu et al. 2010; Skousen et al. 2011). Large woody debris can ameliorate soil temperature and moisture extremes through provision of shelter (Haskell et al. 2012) and also increases surface roughness, providing microsites for vegetation establishment. Interestingly, recent research suggests that inorganic and inert substrates such as bricks could also serve this purpose (Bijman, Landhäusser and 
Macdonald, unpublished). Large woody debris can also be used to restrict access by humans or other animals, such as predators, to a reclaimed site. Wood chips and mulch have also been explored as reclamation amendments (McConkey et al. 2012). For example application of a woody mulch covering to unweathered gray sandstone materials improved tree growth to the level observed in brown sandstone materials (Wilson-Kokes et al. 2013b). However, these types of finer woody debris can insulate the ground (creating late thaw), alter nutrient dynamics, and impede emergence and establishment of vegetation (Landhäusser et al. 2007; Vinge and Pyper 2012) and thus their use should be confined to shallow depths and for specific objectives.

Some regulatory frameworks are, to some extent, supportive of practices aimed at creation of topographic heterogeneity at a variety of scales. For example, a key provision of the SMCRA for the mountainous Appalachian coal region in the USA is landform reconstruction to "approximate original contour" and restoration of landform stability. "Approximate" was used because Appalachian rocks "swell" from 10 to $30 \%$ after blasting so the resulting landform may have slightly different forms and elevations than what existed prior to mining (Skousen and Zipper 2014). State regulations in the USA generally require landform stability and this is based on slope steepness and length, material properties such as particle size and texture, as well as compaction criteria. Water management is based on performance standards for water quality, stream shape and size, storm-water management, and pond number and size relative to the size of the disturbed area.

In the oil sands mining region of Alberta, Canada, landform reconstruction is based on creating landforms that meet the criteria for geotechnical stability while also functioning to regulate water flow through the landscape (Devito et al. 2012). There is a need to ensure adequate supply of moisture to support growth of forest vegetation across a diversity of topographic positions and aspects while at the same time less suitable overburden material (e.g., saline-sodic materials) might need to be spatially separated from the rooting zone. Topographic heterogeneity is modelled on the natural landscape, and relationships of forest ecosite types with topography and soils are used as a guide (e.g., Beckingham and Archibald 1996). Landforms are constructed with relatively mild topographic relief with the aim to establish a diversity of forest ecosystem types on the upper positions, and wetlands in the lower topographic positions (Rowland et al. 2009).

\section{Soil establishment and development}

The placement of a suitable rooting medium is a critical element in reclaiming surface mined lands, as soil serves as the foundation of the new ecosystem (Zipper et al. 2013). Soils developing on reclaimed sites are highly modified, as compared to native soils, in terms of their physical, chemical, and biological properties and their vertical arrangement into distinct horizons; indeed a new classification system has been developed for such soils, termed Anthroposols in Canada (Naeth et al. 2012), Udorthents in the USA (Sencindiver and Ammons 2000), and Technosols in the world reference base for soil resources (IUSS Working Group WRB 2006). Regulations in many jurisdictions require the salvage and stockpiling of topsoil for later use during reclamation; e.g., the SMCRA in the USA, EPEA approvals of oil sands mines in Alberta, Canada, ministerial approvals for bauxite mining in Western Australia. In many European countries topsoil salvage is only required when reclaiming to agricultural land. Native topsoil provides organic matter, soil fauna and microorganisms, native plant propagules and helps maintain nutrient capital on the site 
thus facilitating re-establishment of nutrient cycling (Grant et al. 2007; Skousen et al. 2011; Mackenzie and Naeth 2010; Macdonald et al. 2015). However the nutrient and biological quality of topsoil decreases during stockpiling (Abdul-Kareem and McRae 1984; Grant et al. 2007; Mackenzie and Naeth 2010). Salvaged top soil is a valuable "living resource" and it should be used/redistributed as soon as possible after salvage (Grant and Koch 2007; Koch 2007; Macdonald et al. 2015; Zipper et al. 2013).

\section{Importance of the soil organic component}

Because of the proportionally higher surficial versus belowground litter additions in forest soils a significant fraction of the total ecosystem carbon often accumulates on top of the mineral soil to form several partially decomposed organic horizons, collectively defined as the forest floor. This is particularly true of boreal forests, where the forest floor alone may contain as much carbon as the entire aboveground vegetation (Goodale et al. 2002), representing a storehouse of nutrients and a major determinant of biogeochemical fluxes (Harden et al. 1997; Prescott et al. 2000). Vegetation type also has a direct bearing on soil carbon accumulation; for example boreal coniferous forest stands showed greater forest floor biomass but higher mineral soil carbon than deciduous or mixed stands (Kishchuk et al. 2014; Laganière et al. 2013). In contrast, warmer, temperate and tropical forests have minimal forest floor accumulation, but relatively more organic matter is typically found deeper in the mineral soil (Vogt et al. 1995). These clear differences among ecosystems should be carefully considered when reconstructing forest soils and re-establishing nutrient stocks so as to ensure that restoration practices are tailor-made for each ecosystem type and its associated climatic conditions.

Soil carbon is often used as a proxy for soil quality and is a good indicator of ecosystem recovery in post-mining soils (Frouz et al. 2009; Turcotte et al. 2009). Results from studies using chronosequences post-fire and post-harvesting indicate that soil carbon may return to pre-disturbance levels after about three decades in boreal forests (Norris et al. 2009), while recovery of soil carbon in secondary tropical forests takes between 20 and 100 years (Martin et al. 2013). In post-mining soils where no organic amendment is used, the potential for carbon accumulation is large (Akala and Lal 2000), although carbon levels may not recover to those of natural soils, even after several decades (Zipper et al. 2013). A meta-analysis of carbon storage during post-mining soil development showed that most sites reached the pre-mining level of soil organic carbon within 20 years. However, vegetation types (grassland, deciduous forest, coniferous forest) showed differences in the temporal trend in rate of organic matter accumulation, effects of temperature, and where the organic matter was stored (mineral soil versus litter, fermenting litter and humus layers) (Vindušková and Frouz 2013). Overall, the best results in terms of organic matter accumulation seemed to be achieved under the natural vegetation type of a given biome (Vindušková and Frouz 2013).

Whether it is native to the soil or added as an amendment, organic matter can improve many if not all of the key chemical and physical characteristics of forest soils, including its total nutrient stocks, its aggregation, and its water holding capacity (Larney and Angers 2012; Quideau et al. 2013a). In terms of soil biological properties, however, organic amendments (even those derived from local topsoil) may not provide the same advantage as native organic matter (Vetterlein and Hüttl 1999). Clear inter-relationships are apparent between vegetation, soil organic matter, and soil microbial communities of natural forests (Merilä et al. 2010) but these linkages may be disrupted in post-mining soils, even when organic amendments are applied (Quideau et al. 2013b). For instance, a measurable 
evolution of organic matter composition with time was reported in chronosequences of reconstructed boreal soils (Sorenson et al. 2011), but parallel changes in the soil microbial communities were much harder to establish (Dimitriu et al. 2010; Insam and Domnsch 1988). The main biological benefit of organic amendments may be to promote plant growth-hence indirectly, rather than directly, affecting soil biodiversity (Hahn and Quideau 2013). Ongoing advances in our fundamental understanding of the complex interactions between plants, microorganisms, and soil carbon processes (e.g., Averill et al. 2014) should provide some of the answers needed to improve use of organic amendments during forest restoration.

\section{Soil microbial processes}

Physical, chemical, and biological components of soil play important roles in the development of functioning ecosystems on severely disturbed lands and these different factors are not isolated, but rather interact with one another in important ways (Rowland et al. 2009). Re-establishment of decomposition and nutrient cycling processes is an essential aspect of post-mining forest restoration (Grant et al. 2007). Microorganisms are essential for nutrient cycling, especially $\mathrm{N}$ and $\mathrm{C}$ (Mummey et al. 2002; Ingram et al. 2005; Littlefield et al. 2013), on severely disturbed mine sites. They also have important beneficial and pathogenic interactions with plants (e.g., Grant and Koch 2007; Jasper 2007).

Soil bacteria typically fall into the r-strategists category of organisms adapted to take advantage of resource changes and disturbances while fungi are more typically slower growing and more conservative K-strategists (Sylvia et al. 2005). Thus, undisturbed forest soils tend to be dominated by fungi, whereas forest soils that have been recently disturbed have lower numbers of fungi and higher numbers of bacteria (Dimitriu et al. 2010). Mummey et al. (2002) found that fungal biomarkers were highest under plant canopies and were also positively correlated with soil organic matter.

Vegetation composition affects organic matter content and quality on reclaimed mine sites, in turn affecting the composition of microbial communities (Mummey et al. 2002; Grant et al. 2007; Frouz et al. 2009; Sorenson et al. 2011; Macdonald et al. 2012). Sorenson et al. (2011) found that coniferous stands were linked with fungal presence, whereas aspen stands had a stronger bacterial component. The type of soil replacement or substrate amendment can be clearly linked with differences in both vegetation (Angel et al. 2008; Miller et al. 2012; Wilson-Kokes et al. 2013a) and microbial biomass and composition (Machulla et al. 2005; Palumbo et al. 2004; Chodak and Niklinska 2010). Vegetation affects soil microbial communities by the quantity and quality of litter while microbes, in turn, influence re-vegetation success (Jasper 2007).

Many plant species require microbial symbionts for their germination and growth. For example, at least $75 \%$ of native plant species in jarrah forests form mycorrhizal relationships (Jasper 2007). Use of, or amendment with, topsoil or O-horizon material can introduce both soil microorganisms and plant propagules (Koch 2007; Hall et al. 2010; Mackenzie and Naeth 2010; Zipper et al. 2013). Subsequently, litter layer development is key to establishment of diverse and abundant mycorrhizal communities (Jasper 2007). On restored bauxite mines in Australia, mycorrhizal communities can recover to those in unmined jarrah forest within 10-15 years when soil handling practices promote survival of microorganisms and there are nearby unmined forests that can serve as source populations (Jasper 2007).

On the other hand, some microorganisms act as pathogens, and in this case mine spoils may offer a more hospitable (i.e., pathogen-free) medium than would forest soils that have 
not been subjected to severe disturbance. For example, the potential of the American chestnut (Castanea dentata (Marshall) Borkh.) to thrive on surface-mined lands is due in part to the lack of pathogenic Phytophthora in newly created soils (French et al. 2007; Jacobs 2007; Jacobs et al. 2013).

\section{Soil fauna}

The soil micro-flora plays a crucial role in the decomposition of plant litter (Anderson and Ineson 1984; Lavelle et al. 1997). While the soil fauna contributes little to plant litter mineralization, it does affect formation of various biogenic structures such as pores and aggregates, and influences the distribution of organic matter in the soil profile (Lavelle et al. 1997; Ponge 2003; Frouz 2013; Frouz et al. 2013a). This, in turn, affects soil characteristics and processes such as porosity, infiltration, water holding capacity, microbial biomass, fungal:bacterial ratio and carbon storage (Frouz et al. 2013a, b, d; Frouz and Kuráž 2013).

Colonization of post-mining soils by soil biota will be affected by fauna available in the surrounding landscape, the substrate and vegetation of the post-mining site, distance from an undisturbed ecosystem, and migration barriers such as mines or unsuitable vegetation (e.g., Majer et al. 2007). Generally, dry grassland soils are dominated by root feeding soil fauna while wetter forest soils are dominated by a saprophagous fauna (Frouz et al. 2013b). What is a good migration corridor for one group may be a barrier for another. For example, ground crawling saprophagous macrofauna may migrate well in dense forest patches but such sites can be a barrier for some flying arthropods (Frouz et al. 2013b).

Litter properties, in particular the $\mathrm{C}: \mathrm{N}$ ratio, will strongly affect humus form development and, in turn, soil fauna composition of the reclaimed site. Soil under trees producing slowly-decomposing litter with a high $\mathrm{C}: \mathrm{N}$ ratio, high tannin content, and wax cuticle, is colonized mainly by soil meso- and micro-fauna which contribute little to bioturbation and mixing of organic matter and mineral soil (Frouz et al. 2001; Ponge 2003). As a consequence, a mor type of humus with a thick fermentation (Oe) layer can develop (Ponge 2003). This, in turn, supports high fungal biomass and high density of soil meso- and micro-fauna (Frouz et al. 2001, 2013b, d). Studies in the Czech Republic showed that mesofauna density on reclaimed sites can reach densities comparable to undisturbed forest within 15-20 years (Frouz et al. 2013c). On the other hand, in forests receiving litter with a lower $\mathrm{C}: \mathrm{N}$ ratio soil macrofauna activity contributes to litter fragmentation, mixing and bioturbation leading to development of a moder or even moder-mull type humus (Ponge 2003). This is associated with higher microbial biomass, and often with higher soil carbon (Frouz et al. 2013d).

\section{Re-establishment of vegetation}

A complex above- and below-ground vertical stratification characterizes most natural closed-canopy forest ecosystems and reconstructing this state after resource extraction is a fundamental objective in forest reclamation and restoration (Gorman et al. 2001; Skousen et al. 2006; Grant and Koch 2007; Macdonald et al. 2012). The eventual plant community that develops on reclaimed mine lands will be a function of: landform and topography, local climate/weather patterns, soil properties, vegetation re-establishment treatments, subsequent disturbance, wildlife impacts, and land management (e.g., Angel et al. 2008; 
González-Alday et al. 2008; Burger and Fannon 2009; Tropek et al. 2013). Re-establishment of a closed canopy consisting of native tree species can help promote establishment of a diverse native understory plant community (e.g., Parrotta et al. 1997; Koch 2007). Further, vegetation re-establishment is critical for rebuilding nutrient capital, facilitating soil development, and supporting re-colonization by native vertebrate and invertebrate fauna (Majer et al. 2007; Grant et al. 2007; Nichols and Grant 2007).

\section{Creating the conditions for vegetation establishment}

When choosing species for reclamation, it is important to consider site characteristics including available moisture, soil texture, salinity and $\mathrm{pH}$, soil fertility and nutrient availability (Purdy et al. 2005; Moreno-de Las Heras et al. 2008; Zipper et al. 2011a; Davis et al. 2012). Soil moisture availability is particularly important for vegetation development (Huang et al. 2013). In the northern hemisphere, the northern aspect of hillsides often has greater soil moisture, which can result in more rapid establishment of vegetation (González-Alday et al. 2008). Coarsely textured soils on upper slopes often have very low available soil moisture, even in moist climates, and so require drought tolerant species (Zipper et al. 2011a). Excessive soil moisture can also occur on mine reclamation sites, often in seeps on the lower half of slopes or at the surface of areas with heavily compacted soils where water cannot infiltrate into the soil (e.g., Devito et al. 2012). Understory species classified as facultative wetland species are good choices for these areas, and for areas of compacted material where low soil aeration favors flood-tolerant species (Moreno-de Las Heras et al. 2008).

Soil chemical properties will influence re-vegetation success. Soil liming and fertilization can make mine soils more suitable for vegetation establishment if conditions are limiting (Grant et al. 2007; Skousen and Zipper 2010) although fertilization can lead to increased cover and richness of exotic species (Norman et al. 2006). Mine soils with high levels of heavy metals can be treated to reduce their bioavailability or metal-tolerant plant species can be chosen for revegetation of such sites, but it is important to consider whether these species accumulate metals in foliage (Wong 2003). Similarly, saline or sodic spoils can be treated but may also require the selection of salt tolerant species, which may be available from naturally saline sites within the mining region (Purdy et al. 2005). If the pH of the reclaimed site differs from that of the surrounding areas it will be particularly important to actively establish site-specific vegetation because there may not be suitable species available to colonize the site from adjacent areas and natural succession will proceed slowly (Skousen et al. 1994; Moreno-de Las Heras et al. 2008).

The nature of the overburden material has an important influence on the physical and chemical properties of the developing soil, in turn influencing re-vegetation success. This is particularly well illustrated by reclamation of coal mining sites in the eastern USA. Early reclamation efforts (1930s-1970s) involved planting of trees into loose, uncompacted weathered overburden (Potter et al. 1955; Zeleznik and Skousen 1996; Gorman et al. 2001; Ashby 1998). These sites showed good tree growth and rapid recruitment of adjacent native trees resulting in diverse forest after 10-20 years (Skousen et al. 1994, 2006; Tryon 1952). Later the influence of mine soil properties on tree growth was explored in more detail (Andrews et al. 1992; Ashby 1998; Daniels and Amos 1985; Johnson and Skousen 1995; Rodrigue and Burger 2004; Torbert et al. 1990; Zeleznik and Skousen 1996).

While the SMCRA now requires salvage and reuse of topsoil, use of substitute topsoil materials is often permitted. Overburden rock types that are used as "topsoil" include weathered and unweathered sandstones, siltstones, and shales (Smith and Sobek 1978). When placed on the surface these materials will weather and transform over time into a 
variety of mine soil materials with vastly different physical and chemical properties (Sencindiver and Ammons 2000). Overburden materials have lower nutrients than native topsoils (Sobek et al. 2000) increasing the need for use of fertilizers and mulches (Mays et al. 2000). Rock spoils are also initially devoid of pedogenic organic C (Daniels and Amos 1985) and it will accumulate only slowly on re-vegetated mine soils (Amichev et al. 2008).

Weathered sandstones produce soils with a sandy loam texture and slightly acidic $\mathrm{pH}$ (4.5-6.0), both of which are conducive to tree growth (Torbert and Burger 2000; Burger et al. 2005b; Skousen et al. 2006). Siltstone and shale materials weather rapidly but the resulting soils have finer textures and can thus be prone to compaction or settling (Casselman et al. 2006). Unweathered gray sandstone, siltstone and shale materials result in soils with slightly higher pH (from 6.5 to 8.5), in which trees can survive but grow slowly (Angel et al. 2008; Miller et al. 2012). Soluble salts, which are detrimental to tree growth, are higher in fine textured soils derived from unweathered, shale and siltstone overburden as compared to soils derived from weathered sandstone (Torbert et al. 1990; Rodrigue and Burger 2004).

Overall, longer-term survival and growth of trees is better in weathered brown materials than in unweathered gray sandstone, siltstone, shale (Angel et al. 2008; Emerson et al. 2009; Wilson-Kokes et al. 2013a) (Table 1). This has been attributed to a slightly acid pH, low soluble salts, good drainage and aeration, and better water retention compared to most unweathered rock materials. However gray unweathered sandstone can undergo rapid physical and chemical change (Haering et al. 2004) such that soil development can begin within 3 years (Sencindiver and Ammons 2000; Bendfeldt et al. 2001). Further, unweathered rocks generally contain more base cations (Zipper et al. 2013; Wilson-Kokes et al. 2013a) and these are especially important to species such as tulip poplar, ash, maples, and some oak species (Rodrigue and Burger 2004; Burger and Fannon 2009). When rock spoils have aged sufficiently to leach soluble salts and stabilize in $\mathrm{pH}$ (i.e., 10-20 year), soils with $\mathrm{pHs}$ in the slightly acid to circumneutral range can in some cases be more productive for native hardwoods than more acidic soils (Rodrigue and Burger 2004; Burger and Fannon 2009). A mix of native top soil, weathered sandstone and unweathered rock materials could result in optimal mine soil quality for restoring native forest productivity in the long term (Burger and Fannon 2009; Rodrigue and Burger 2004).

Table 1 Volume (height $\times$ diameter $^{2}$ in $\mathrm{cm}^{3}$ ) of 10 planted tree species on topsoils derived from weathered brown versus unweathered grey overburden 3and 8- years post-establishment at Catenary Coal Mine in Kanawha County, West Virginia

There was a significant difference between the two soil types in each time period

\begin{tabular}{|c|c|c|c|c|}
\hline \multirow[t]{3}{*}{ Species } & \multicolumn{4}{|c|}{ Treatments } \\
\hline & \multicolumn{2}{|l|}{3 years } & \multicolumn{2}{|l|}{8 years } \\
\hline & Brown & Gray & Brown & Gray \\
\hline Black cherry & 523 & 155 & 930 & 1981 \\
\hline Black locust & 1294 & 115 & 5324 & 328 \\
\hline Dogwood & 209 & 19 & 2534 & 1064 \\
\hline Redbud & 124 & 84 & 2058 & 1762 \\
\hline Red oak & 132 & 32 & 3609 & 397 \\
\hline Sugar maple & 44 & 36 & 354 & 108 \\
\hline Tulip poplar & 591 & 59 & 3910 & 284 \\
\hline White ash & 204 & 33 & 3500 & 711 \\
\hline White oak & 108 & 38 & 3027 & 74 \\
\hline White pine & 34 & 10 & 762 & 154 \\
\hline Mean & 308 & 55 & 3913 & 449 \\
\hline
\end{tabular}


On reclaimed sites in the boreal forest, cover soil material and their nutrient and carbon status appear to play a role in determining revegetation success (Wolken et al. 2010; Pinno et al. 2012, 2014). On naturally saline sites in the boreal forest, Lilles et al. $(2010,2012)$ found that forest vegetation could establish on sites with extreme values of salinity and high $\mathrm{pH}$ as long as these were confined to the lower soil profile (40 $\mathrm{cm}$ or deeper). White spruce (Picea glauca (Moench) Voss) grew slowly on saline sites but was able to survive and form good forest cover (Lilles et al. 2012). Productivity of trembling aspen was quite good on saline sites that had good soil moisture and nutrient availability but there was some evidence of declining productivity over time, which could be related to restrictions on the suitable rooting zone (Lilles et al. 2012).

\section{Planting trees and shrubs}

The selection of tree species for a reclamation site should consider the influence of landform, topography, local climate/weather, and soils. As soil conditions on reclamation sites are often highly variable, planting a mixture of tree species is often advisable; this also provides of a variety of potential habitats and allows the developing forest to build resistance and resilience to pests and other stressors (Parrotta et al. 1997; Davis et al. 2012). Deploying tree species representing different life histories, tolerances to stress, and successional status can have other benefits, such as increases in forest productivity through facilitation and resource partitioning, as well as increases in diversity of associated aboveand below-ground flora and fauna. For example, when three upland boreal tree species were planted in salvaged lowland peat, upland mineral forest floor, and a sub-soil, initial soil mycorrhizal diversity was driven by tree species and not the substrate type (Fig. 3).

On most forest reclamation sites, the use of direct seeding or a reliance on natural seed rain for tree regeneration is generally avoided because tree establishment tends to be slow and irregular and sites tend to become dominated by less desirable, wind-dispersed species. Tree planting, therefore, remains one of the most effective strategies in re-establishing forest cover in areas affected by industrial disturbance (e.g., Parrotta et al. 1997). Good progress has been achieved, however, with re-establishment of native jarrah forest following bauxite mining in Australia through sowing of diverse native tree seed mixes and use of surface soil materials (Grant and Koch 2007). One aim of rapidly establishing trees on a reclamation site is to quickly create a continuous tree canopy in order to suppress the establishment of shade intolerant, "weedy" herbs and shrubs that could hinder the development of native forest understory vegetation.

The target seedling concept is based on "fitness for purpose" in which limiting factors of reclamation sites are used to determine ideal seedling stock types, with species- and sitespecific considerations. Access to high quality nursery planting stock helps to promote and accelerate forest reclamation, as environmental conditions on reclamation sites are generally much more stressful than those characterizing typical reforestation sites (Davis et al. 2010). However, much of the knowledge regarding seedling production techniques is based on commercially important tree species used for reforestation (Oliet and Jacobs 2012). Nursery stock quality specifications for the diversity of tree species desired for reclamation is still in development or in some cases unavailable.

Seedling physiological and morphological characteristics can be manipulated during nursery culture conferring an advantage on stressful reclamation sites. For example high tissue $\mathrm{C}$ reserves in aspen (Populus tremuloides Michx.) seedlings positively affect field performance (Landhäusser et al. 2012b). On nutrient-limited sites, nutrient loading during the nursery phase allows for luxury consumption of nutrients in plant tissues (Birge et al. 


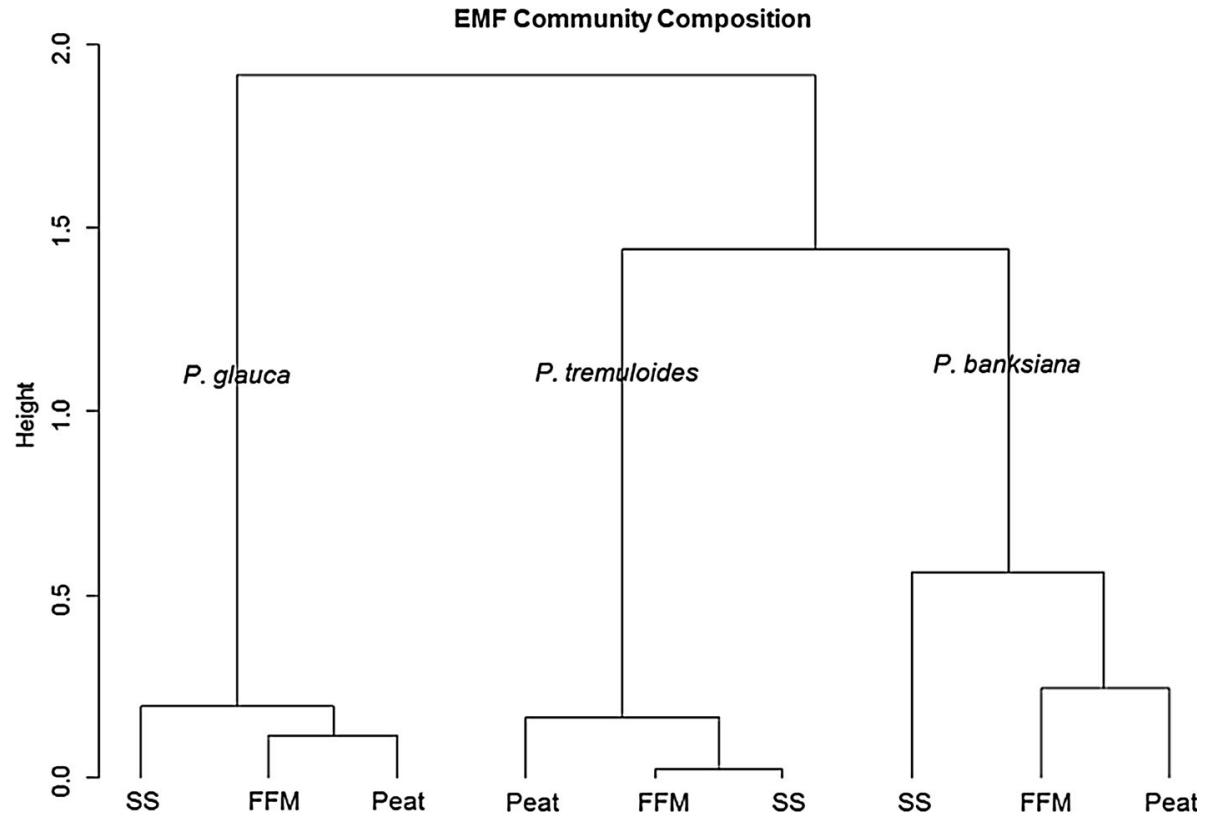

Fig. 3 Results of cluster analysis of ectomycorrhizal fungal (EMF) communities showing the influence of tree species (white spruce (Picea glauca), trembling aspen (Populus tremuloides); jack pine (Pinus banksiana)) and three different reclamation soil capping substrates (SS sub-soil, FFM forest floor material, Peat peat)

2006; Salifu and Jacobs 2006), which may then be re-translocated to promote growth following field planting (Salifu et al. 2009; Schott et al. 2013). On exposed upland reclamation sites where soil moisture is often limiting, seedlings with high root-shoot ratios should be better adapted to deal with the evaporative demand. However, there are often trade-offs between physiological and morphological characteristics such as tissue storage of nutrient and total C reserves and the balance of root-shoot and total seedling size (VillarSalvador et al. 2012). For example, tall and large trembling aspen seedlings that had high total nonstructural carbon reserve but lower tissue concentration of reserves, performed more poorly after outplanting than did a smaller stock type with higher tissue concentrations and root to shoot ratios (Landhäusser et al. 2012a; Fig. 4). In contrast, on the same
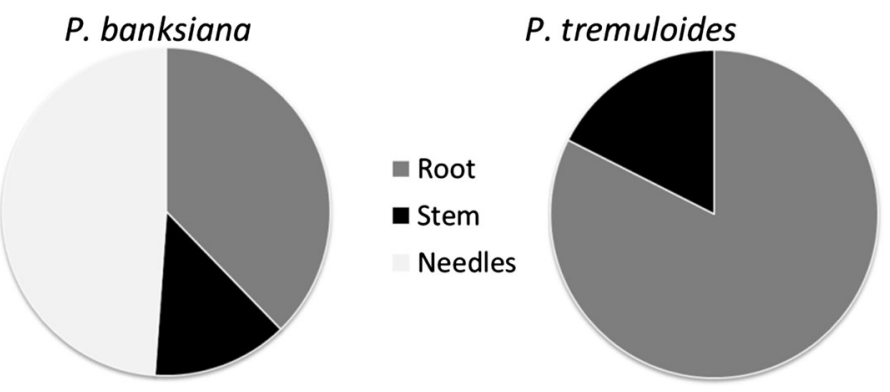

Fig. 4 Distribution of tissue carbon reserves in organs of dormant jack pine (Pinus banksiana) and trembling aspen (Populus tremuloides) seedling stock prior to outplanting 
site large jack pine (Pinus banksiana Lamb.) seedlings with high total carbon reserves performed better after outplanting, while tissue reserve concentrations did not play a role (Goeppel, Landhäusser et al. unpublished data). These differences are likely driven by the relative location of reserves in the seedlings. While the majority of carbon reserves are stored in the needles of jack pine seedlings, in aspen seedlings the majority of reserves are stored in the roots (Goeppel et al. unpublished).

In addition to seedling stock characteristics, site and substrate conditions can be manipulated during reclamation to reduce stress on the outplanted seedlings (Franklin et al. 2012; Löf et al. 2012). Other factors such as seedling handling (Davis et al. 2010), planting procedures, timing of planting (Landhäusser et al. 2012b), and microsite/planting spot selection will also influence the successful establishment and growth of tree seedlings on reclamation sites.

\section{Natural regeneration}

In some circumstances, natural regeneration in post-mining sites can result in development of forest stands (Frouz 2013; Fig. 5). Forest stands naturally establishing on reclamation sites are typically formed by tree species with air borne seeds such as Populus spp. and Betula spp. (Frouz et al. 2013c). Grading of the surface or application of topsoil can actually reduce natural regeneration of trees, increase compaction (inhibiting tree rooting) and increase the abundance of competing ground vegetation (Ashby 1998; Frouz 2013; Skousen et al. 2011; Zeleznik and Skousen 1996). Deep ripping can be used to improve compacted soils (Grant and Koch 2007). Successful natural establishment of trees by seed is facilitated by the presence of an ungraded rough surface that can trap seeds and serve as a favorable regeneration microsite, partly because these will tend to host less competitive vegetation (Frouz 2013; Frouz et al. 2011; Landhäusser et al. 2010). Natural regeneration of trembling aspen on reclaimed mine sites was facilitated by concave microsites and mixed mineral-organic substrates (Schott et al. 2014).

Natural regeneration can result in different tree composition and lower woody biomass than in planted forest (Frouz et al. 2013c; Skousen et al. 1994) but these differences are most pronounced in the early stages of development (e.g., in the Czech Republic, first 20 years) (Frouz 2013). Indeed, natural regeneration can sometimes result in greater species diversity and more rapid re-development towards natural vegetation composition than active reclamation by planting of trees; this is particularly true if the latter involves planting of non-native species and/or re-contouring the site and causing disturbance to naturally establishing vegetation (Hall et al. 2010; Hodačová and Prach 2003). Natural regeneration can be less costly and can result in a forest stand comprised of locally adapted species and genotypes resulting in greater floral and faunal diversity than actively reclaimed sites (Prach et al. 2001; Frouz 2013; Skousen et al. 2006). On the other hand, the outcomes of natural regeneration are less predictable and generally much slower. Establishment of forest on coal mine lands in the eastern USA by means of natural regeneration was extremely slow, even where soils were favorable (Zipper et al. 2011a). This can be attributed to establishment of non-native invasive plant species (Zipper et al. 2011a) and "arrested" development of vegetation succession on reclaimed land with compacted soils and heavy ground cover (Groninger et al. 2007; Skousen et al. 2009). Further study on options for promoting natural revegetation on reclaimed mine sites is needed. A prerestoration survey of sites could help identify areas that already have promising natural vegetation development. 

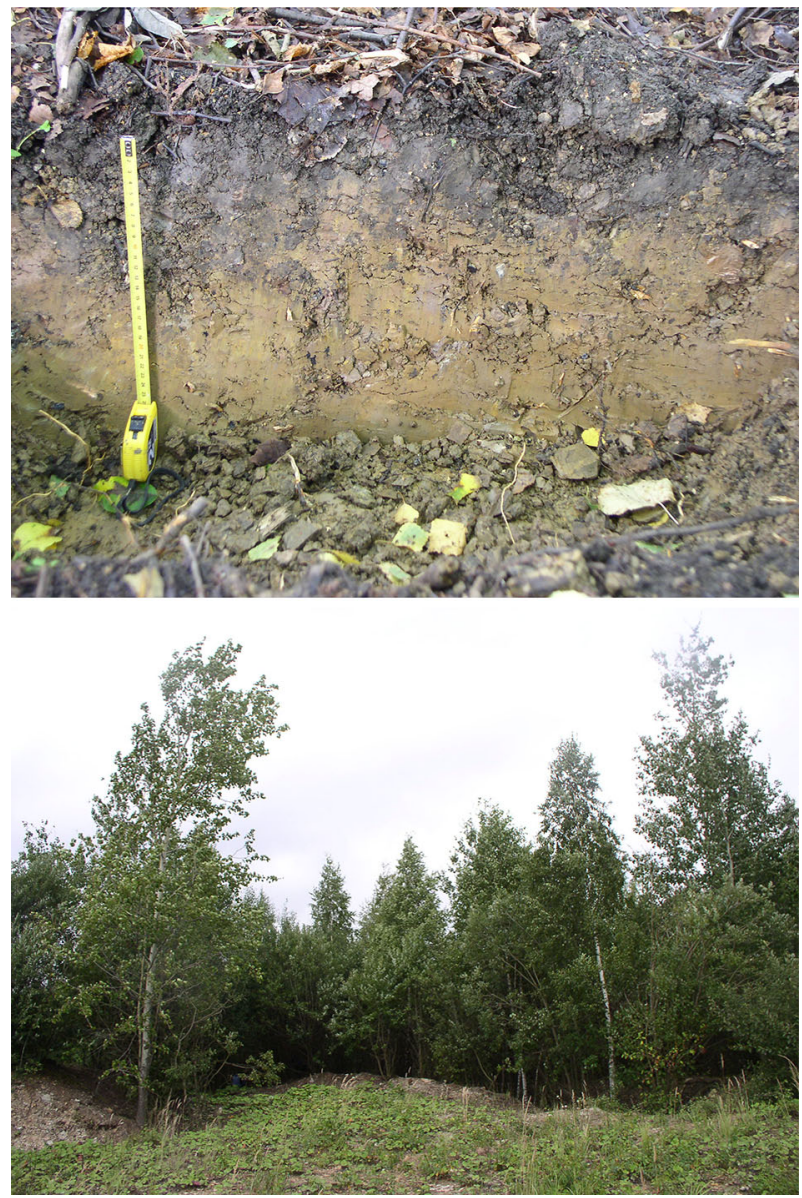

Fig. 5 Spontaneous soil formation on overburden under an alder plantation after 30 years (top) and spontaneous regrowth on overburden about 25 years after soil heaping (bottom); Sokolov Czech Republic; photo: J. Frouz

\section{Facilitating re-establishment of forest understory vegetation}

One of the greatest challenges to re-establishment of a natural forest understory community is accessing a diversity of native plant propagules. Concerted research efforts focused on restoration to jarrah forest after bauxite mining in Australia have improved availability of native species seed mixes and understanding of their dormancy mechanisms (Grant and Koch 2007). Unfortunately, in most other regions native plant propagules are not commercially available (Smreciu and Gould 2013) and even if collection is possible, there is often insufficient knowledge of protocols for their nursery propagation (Harrington et al. 1999; Macdonald et al. 2012). Adjacent unmined forest can serve as an important source of plant propagules that can be dispersed to the reclaimed site by wind or animals (Parrotta et al. 1997). However, when large areas are subject to disturbance by mining, there may be no nearby sources of native species propagules for dispersal onto the reclamation site. 
Forest floor material (including the litter, fermenting litter and humus layers) and surface mineral horizons) houses a rich bud and seed bank, which serves as the main source of native species propagules for vegetation re-establishment following many natural and human-caused disturbances (Greene et al. 1999; Paré et al. 1993; Schimmel and Granstrom 1996). The potential of this material for use in reclamation was recognized in Australia as early as the 1970's (Grant and Koch 2007) and this approach has gained recent interest in North America (e.g., Mackenzie and Naeth 2007; Cohen-Fernandez and Naeth 2013; Skousen et al. 2011; Macdonald et al. 2015).

Peat-mineral mix (organic layers and surface mineral soil horizons salvaged from nearby peatland forest sites) was initially the most commonly used organic amendment in oil sands mining reclamation (Fung and Macyk 2000). However, use of forest floor material as an organic amendment resulted in better nutrient availability and greater plant richness and abundance than does peat-mineral mix (Mackenzie and Naeth 2010; Mackenzie and Quideau 2012). Forest floor material results in more rapid development towards native upland forest vegetation while peat provides propagules of peatland-associated species (Mackenzie and Naeth 2010; Pinno unpublished). Oil sands sites reclaimed using forest floor material (vs. peat-mineral mix) had higher cover of trees, shrubs, and forbs, and the soil microbial community composition was converging more quickly towards that of natural upland forest (Hahn and Quideau 2013). Plant propagules in forest floor material lose their viability quickly if the material is stockpiled prior to placement but direct placement of forest floor material can overcome this problem and has shown promise in trials in several different locations (Holmes 2001; Iverson and Wali 1982; Koch et al. 1996; Rokich et al. 2000; Tacey and Glossop 1980). For example, direct placement of forest floor material on a coal mine reclamation site in Alberta resulted in rapid ( $\leq 3$ year) establishment of 65 native species, 30 of which were characteristic of mature, closed boreal forest (Macdonald et al. 2015). For jarrah forests being restored following bauxite mining in Australia, return of about $70 \%$ of native understory species can be achieved through direct placement of surface soil materials (Koch 2007).

Both the depth of salvage and placement of forest floor material influence vegetation reestablishment on the reclamation site. Because seed density declines with depth in the soil profile salvaging to greater depth can dilute the seed bank while salvaging at shallower depths could waste some of the propagule pool (Putwain and Gillham 1990; Tacey and Glossop 1980; Macdonald et al. 2015). Placement depth, in turn, will influence emergence in a species-specific way (Bowen et al. 2005; Holmes 2001; Tacey and Glossop 1980; Zhang et al. 2001). Studies suggest that shallower salvage results in initially higher total cover while deeper salvage can lead to greater richness and favour establishment of native forest species over the slightly longer term (Rokich et al. 2000; Macdonald et al. 2015; Fig. 6). Depending on the amount of available forest floor material, an option would be to place the material at a different depth than the thickness at which it was salvaged. While use of forest floor material for reclamation holds much promise, even when this material rich in plant propagules is used, revegetation success can be poor if site conditions are too severe (Cohen-Fernandez and Naeth 2013).

\section{Seeding understory vegetation}

Where native species seed mixes are available, for example for the restoration of jarrah forest on bauxite mining sites in Australia, sowing of diverse mixes of native species can lead to much higher richness and cover of native understory plant species than in unsown area (Norman et al. 2006). Still, recovery towards the pre-mined condition may be very 

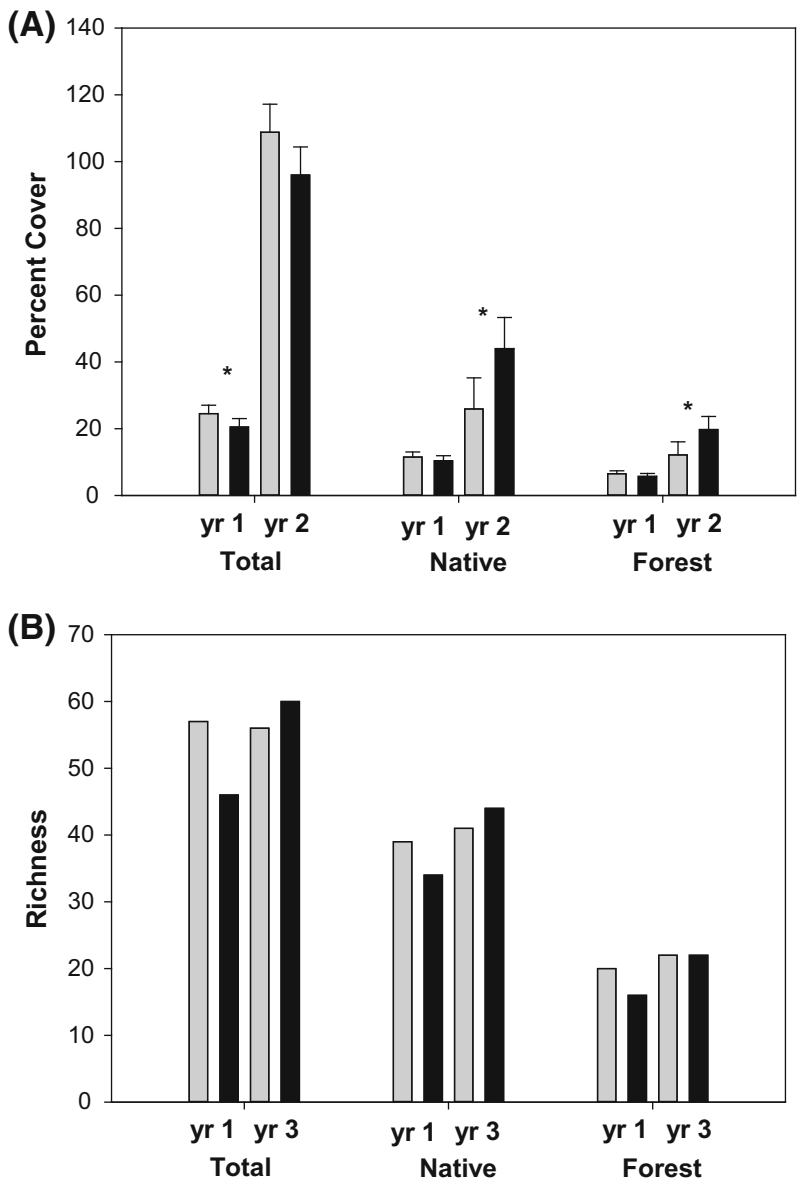

Fig. 6 Comparison of a percent cover (mean and standard error) and $\mathbf{b}$ richness (number of species found in $961 \mathrm{~m}^{2}$ plots) for all species (total), native species and species characteristics of mature boreal forest in year 1,2 or 3 following direct placement of forest floor material at two depths: shallow $(15 \mathrm{~cm})$ and deep $(40 \mathrm{~cm})$. Asterisk indicates a significant difference between depths for that year. Site was a reclaimed coal mine in Alberta (modified from Macdonald et al. 2015)

slow and the plant community can be strongly influenced by the initial composition (Norman et al. 2006; Koch 2007). During restoration of jarrah forests after bauxite mining in Australia, seeding of native species is often complemented with planting of recalcitrant species to achieve higher total native species richness (Grant and Koch 2007).

The diversity and species composition of a seed mix can be the primary factor influencing the species richness and composition of the resulting community (Grman et al. 2013) and thus requires careful consideration for mined areas slated for reforestation. An herbaceous ground cover is often seeded on reclamation sites to control erosion (Fig. 7). Factors usually considered in the selection of species include time of year, availability and cost of seed, plant functional group, soil and site characteristics, and land use goals (Skousen and Zipper 2010). It is important to establish vegetative cover before the annual period of high intensity storms, when most rill development occurs (Hoomehr et al. 2014) 
Fig. 7 Site in Tennessee prepared using the Forestry Reclamation Approach, one year after planting, with coarse woody material visible, and a diverse herbaceous layer that covers approximately $50 \%$ of the ground surface. Photo: J. Franklin

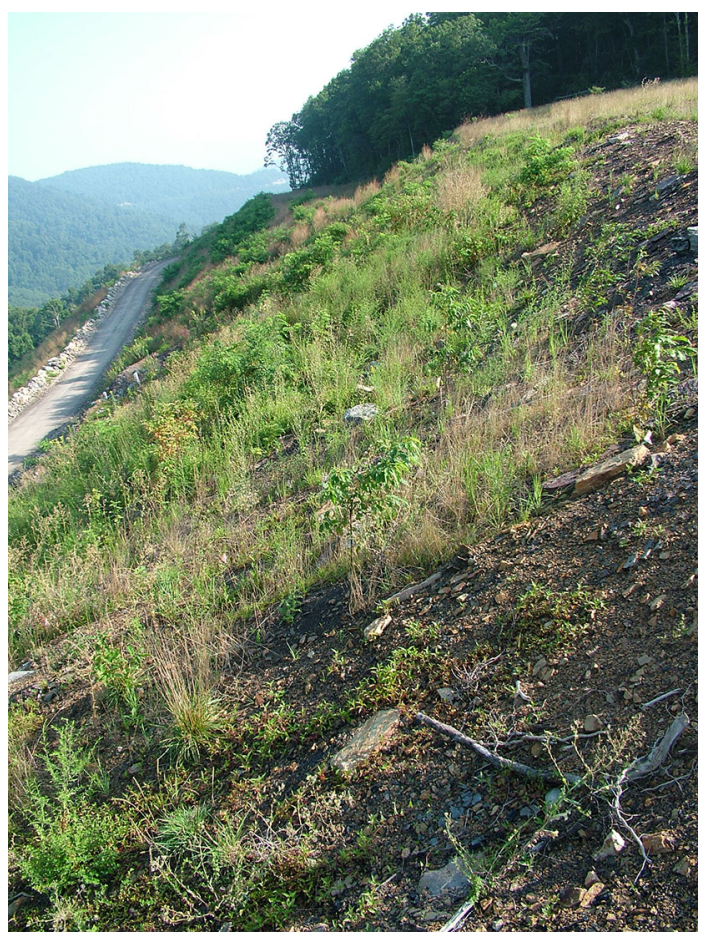

as this can severely hamper vegetative establishment (Moreno-de Las Heras et al. 2008). Therefore the seed mixture should contain at least one species that can germinate and establish quickly to stabilize soils and prevent the seeds of more slowly establishing species from being buried or washed off the site. An annual grain is often used for this purpose, with perennial legumes and grasses included in the seed mix to provide more persistent cover (Skousen and Zipper 2010).

Annual plants provide a cover that establishes quickly which, in addition to stabilizing soil, functions to retain nutrients on the site and provide organic matter, initiating nutrient cycling and soil building processes. Species should be selected based on their ability to germinate and establish in the season in which they are seeded, or as early as possible in the spring, for late seeding dates in northern climates. Native species are typically preferred, but agronomic species are often used for their low cost, reliability over a range of soil types, and well known establishment requirements (Skousen and Venable 2008). Grasses are commonly used as the annual component of the seed mix. Where non-native annuals are used, their persistence or spread can be controlled by using sterile cultivars or species that are not able to complete their life cycle in the climate in which they are planted. Seeding rates should be based on the planting season. Higher seeding rates can be used in later season sowings because annuals will be declining or dead before other species begin to establish. Lower seeding rates should be used when seeding annuals early in the growing season to avoid competition with other components of the developing vegetation.

The objective of establishing perennial vegetation is to provide a ground cover that will eventually be replaced through normal successional processes. Legumes are often included in a seed mixture because of their ability to enrich the soil with nitrogen (e.g., Grant et al. 
2007). If native legumes are not available, short-lived agronomic or wild species of low persistence can be selected. Other perennials, generally grasses or native forbs, can be planted to increase the quality of wildlife habitat and diversity of the plant community. Species with taproots are particularly beneficial for loosening compacted soil (Chen and Weil 2010; Skousen and Zipper 2010).

Cover crops that are often used for initial soil stabilization on reclamation sites (OSVRC 1998; Rowland et al. 2009) and can also serve to inhibit establishment of weedy species while providing temporary shelter for natural forest understory species until a sufficient tree canopy develops. Desirable characteristics for cover crop species include the ability to establish quickly, have a diffuse canopy, and nitrogen fixation (Landhäusser et al. 1996). Macdonald et al. (2015) found that Melilotus officinalis (L.) Pall. planted as a cover crop suppressed undesirable species while not negatively affecting target forest understory species. However, there was evidence that its biennial nature could result in annual alternation with weedy species, in that case hemp-nettle (Galeopsis tetrahit L.).

Several different methods may be used for seeding understory vegetation on a reclamation site, depending on the size of the area and terrain, but choice of seeding method has not been found to influence long-term development of vegetation (Newman and Redente 2001). Hydroseeding is an efficient method for moderately sized sites, and is commonly used on steep slopes or rough terrain where the use of other equipment is difficult (Franklin et al. 2012). Broadcast seeding is generally done by hand and requires no specialized equipment but is obviously suitable only for small areas. Drill seeding uses conventional agricultural equipment to plant seed below the soil surface; this is the preferred method if the soil conditions are suitable but is limited to relatively flat and well-groomed sites. Drill seeding can use lower seeding rates than either hydroseeding or broadcast seeding. Pretreatment of seed to improve germinability can be important for success. For example, it is common to pre-treat seeds of wildfire-adapted species with heat or smoke prior to seeding during jarrah forest restoration following bauxite mining (Koch 2007).

For reforestation, it is preferable to use from seven to 10 species in the ground cover seeding mixture, as this can accelerate the development of vegetation while seeding mixtures of only 3-5 species can delay successional processes (Burger et al. 2009; Kirmer et al. 2012). Often there is a tendency to include too many species in seeding mixtures (up to 25 species!) and this should be avoided because of the waste of seed and the excessive cost. Use of a mixture of genotypes is recommended for the restoration of highly disturbed areas (Lesica and Allendorf 1999) because it can improve the likelihood that some individuals will be tolerant of future conditions. This can be achieved through use of wildcollected seed or mixing seed from several sources or cultivars.

\section{Interactions of understory vegetation with trees}

Although herbaceous cover is often needed to control erosion, dense seeded ground covers can hinder tree establishment and growth, slowing successional development (Burger et al. 2005b; Moreno-de Las Heras et al. 2008; Franklin et al. 2012). Herbaceous vegetation competes with tree seedlings for light, water and nutrients. In conditions of low soil nutrient or water availability, root competition has greater influence than above-ground competition (Putz and Canham 1992). Alternatively, the herbaceous layer can facilitate tree establishment by providing sheltered microsites for establishment. The rapid growth rate of many annual and perennial plants also serves to retain nutrients on site and contribute above and below-ground litter. This initiates nutrient cycling and the development 
of soil biota, and improves infiltration and soil water-holding capacity-all of which aid tree establishment.

The balance of facilitation and competition between trees and ground cover likely depends on environmental factors and the density of the herbaceous cover. Across a range of environments in the eastern USA, survival of tree seedlings planted on mine sites was found to be negatively correlated with the density of ground cover when herbaceous plants covered more than $60 \%$ of the soil (Franklin et al. 2012). At lower densities, the herbaceous layer appears to facilitate tree establishment on some sites while inhibiting trees on other sites. This can be attributed to species-specific differences, neighbor-specific interactions, resource availability and environmental conditions (Eviner and Hawkes 2008). Herbaceous species differ in functional traits and there is evidence that the species composition of planted ground cover influences planted trees. For example, there are numerous reports of non-native forage grasses having a negative influence on tree establishment (Skousen et al. 2009), whereas reports of negative impacts of native species are rare. Plant species composition also influences the soil microbial community on reclaimed sites (Rana et al. 2007), which may have an important effect on tree establishment.

\section{Conclusions and recommendations}

Many of the challenges in restoring forests after severe mining disturbances are common to different regions. Research results and practical experience from different regions provide a strong foundation of principles that can be broadly applied to development of best practices for forest restoration. Based on our synthesis of forest restoration approaches we recommend further elaboration of the Forestry Reclamation Approach (Burger et al. 2005a) as follows:

- Laying the foundation:

- Landform construction should be modelled on natural systems

- Use and handling of overburden to minimize undesirable effects on soil and vegetation redevelopment

- Use overburden, surface soils, woody material to create heterogeneity at a variety of scales

- Soil re-establishment

- Replace topsoil or utilize other organic amendments to more quickly re-establish nutrient cycling and soil development processes

- Use deeper placement of capping materials on poorer overburden

- Revegetation

- Leave residual forest patches nearby when possible to serve as seed sources and propagule banks; manage these on an ongoing basis as a source for natural regeneration of forest plant species

- Facilitate natural regeneration as much as possible 
- Align landform, topography, overburden, soil and tree species to create a diversity of target ecosystem types representative of the natural range of variation

- Plan tree planting at the micro- and meso-scale, not at the landscape scale

- Plant mixes of tree species (e.g., early and later successional species) in mosaics at different scales

- Utilize nursery culture and planting techniques to optimize performance of planted trees

- Plant trees as soon as possible on the site and at high densities to help exclude establishment of weedy vegetation

- Utilize direct placement of forest floor material to more rapidly re-establish native forest herbaceous vegetation

- When sowing or planting herbaceous vegetation use native species as much as possible and select mixes that will have minimal competitive impact on trees

- Sow a cover crop of annuals or short-lived perennials chosen for initial erosion control, desirable properties like nitrogen fixation, and growth forms that will exclude undesirable weedy species while not negatively impacting trees or native understory vegetation

- Plan for subsequent entries onto the reclamation site as necessary to facilitate or manipulate stand development trajectories

Success in reclamation or restoration of forest ecosystems post-mining can be assessed by whether the reclaimed forest is productive and self- sustaining and if it fulfills ecological, economic and social objectives. Achievement of this objective relies upon an integrated approach including: landform construction that will support the desired long-

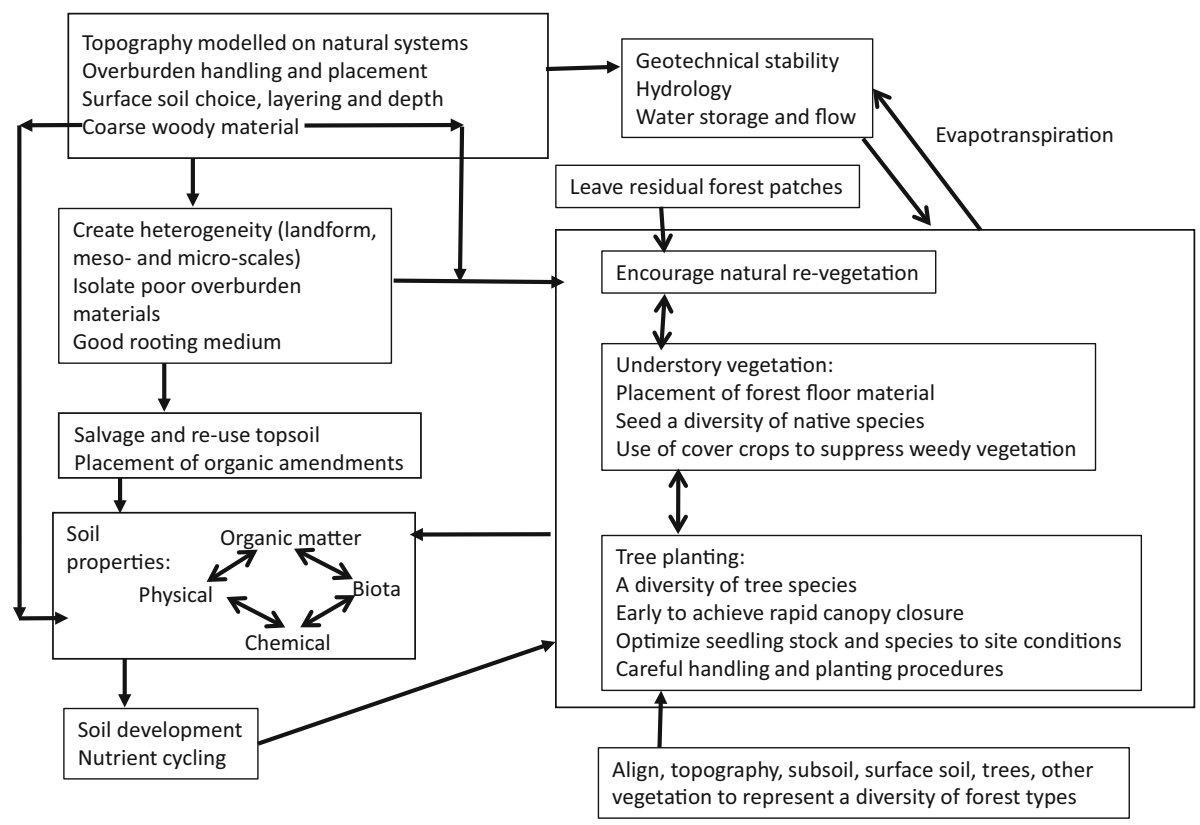

Fig. 8 Conceptual diagram of recommended approaches for forest restoration after severe mining disturbance 
term geotechnical stability and hydrologic processes; careful placement and handling of overburden and surface soil materials to facilitate soil development and vegetation establishment; creation of heterogeneity at a variety of scales; matching of topography, overburden, surface soils and vegetation to support development of a diversity of forest ecosystem types; encouragement of natural revegetation combined with use of surface soil materials, seeding and planting of native species (Fig. 8). With an appropriate foundation of soil and herbaceous cover, nearby native species can recolonize the site, and trees will grow rapidly enough to close the canopy and exclude invasive and weedy species. Microbial communities will develop as organic matter pools grow, spurring nutrient cycling. As the plant community becomes increasingly dominated by native species and forest structure develops, enhanced ecosystem services will be provided. Continuous evolution of regulatory frameworks that acknowledge and accept variation in objectives and outcomes will greatly facilitate forest restoration after severe mining disturbance.

Acknowledgments We thank the many grad students, research assistants, and funding agencies that supported the research summarized herein. The concept for this paper originated at a symposium held at the Society for Ecological Restoration annual meeting in Madison, Wisconsin in October 2013.

Open Access This article is distributed under the terms of the Creative Commons Attribution 4.0 International License (http://creativecommons.org/licenses/by/4.0/), which permits unrestricted use, distribution, and reproduction in any medium, provided you give appropriate credit to the original author(s) and the source, provide a link to the Creative Commons license, and indicate if changes were made.

\section{References}

Abdul-Kareem AW, McRae SG (1984) The effects on topsoil of long-term storage in stockpiles. Plant Soil 76:357-363

Akala V, Lal R (2000) Potential of mine land reclamation for soil organic carbon sequestration in Ohio. Land Degrad Develop 11:289-297

Alfnes E, Kinzelbach W, Aagaard P (2004) Investigation of hydrogeologic processes in a dipping layer structure: 1. The flow barrier effect. J Contam Hydrol 69:157-172

Amichev BY, Burger JA, Rodrigue JA (2008) Carbon sequestration by forests and soils on mined land in the Midwestern and Appalachian coalfields of the U.S. For Ecol Manage 256:1949-1959

Anderson JM, Ineson P (1984) Interaction between microorganisms and soil invertebrates in nutrient flux pathways of forest ecosystems. In: Anderson JM, Rayner AD, Walton DWH (eds) Invertebrate microbial interactions. Cambridge University Press, Cambridge, pp 59-88

Andrews JA, Torbert JL, Johnson JE, Burger JA (1992) Effects of minesoil properties on young white pine (Pinus strobus) height growth. In: Barnhisel R (ed) Proceedings of 1992 American society of mining and reclamation meet, Duluth, MN, 14-18 June 1992. ASMR, Lexington, KY, pp 119-129

Angel P, Davis V, Burger J, Graves D, Zipper C (2005) The Appalachian regional reforestation initiative. US Office of Surface Mining, Appalachian Regional Reforestation Initiative, Forest Reclamation Advisory Number 1. http://arri.osmre.gov/FRA/Advisories/FRA_No.1.7-18-07.Revised.pdf

Angel P, Barton C, Warner R, Agouridis C, Taylor T, Hall S (2008) Forest establishment and water quality characteristics as influenced by spoil type on a loose-graded surface mine in eastern Kentucky. In: Barnhisel R (ed) Proceedings of 2008 American Society of Mining and Reclamation, June 4-8, 2008. Richmond, VA, pp 28-65

Ashby WC (1998) Reclamation with trees pre- and post-SMCRA in southern Illinois. Intl J Surface Mining, Recl Environ 12:117-121

Averill C, Turner BL, Finzi AC (2014) Mycorrhiza-mediated competition between plants and decomposers drives soil carbon storage. Nature 505:543-545

Beckingham JD, Archibald JH (1996) Field guide to ecosites of northern Alberta. Natural Resources Canada, Canadian Forest Service, Northwest Region, Northern Forestry Centre, Edmonton, Alberta. Special Report 5 
Bendfeldt ES, Burger JA, Daniels WL (2001) Quality of amended mine soils after sixteen years. Soil Sci Soc Am J 65:1736-1744

Birge ZKD, Salifu KF, Jacobs DF (2006) Modified exponential nitrogen loading to promote morphological quality and nutrient storage of bareroot-cultured Quercus rubra and Quercus alba seedlings. Scan J For Res 21:306-316

Bowen C, Shuman G, Olson R, Ingram J (2005) Influence of topsoil depth on plant and soil attributes of 24-year-old reclaimed mined sites. Arid Land Res Manage 19:267-284

Brown RL, Naeth MA (2014) Woody debris amendment enhances rclamation after oil sands mining in Alberta, Canada. Rest Ecol 22:40-48

Burger JA, Fannon AG (2009) Forest land capability of reclaimed mined land for seven Appalachian hardwood species. In: Barnhisel R (ed) Proceedings of 2009 American Society for Mining and Reclamation, Billings, MT, May 30-June 5, 2009, Lexington, KY

Burger JA, Graves D, Angel P, Davis V, Zipper C (2005a) The forestry reclamation approach. Forest Reclamation Advisory No. 2. pp 1-4. http://arri.osmre.gov/Publications/Publications.shtm. Accessed 26 March 2013

Burger J, Mitchem D, Zipper C, Williams R (2005b) Herbaceous ground cover effects on native hardwoods planted on mined land. In: R. Barnhisel (ed) Proceedings of American Society Mining and Reclamation conference, Breckenridge, CO, ASMR, Lexington, KY

Burger J, Davis V, Zipper C, Franklin J, Skousen J, Barton C, Angel P (2009) Tree-compatible ground covers for reforestation and erosion control. US Office of Surface Mining, Appalachian Regional Reforestation Initiative, Forest Reclamation Advisory Number 6, July 2009. http://arri.osmre.gov/

Burton PJ, Macdonald SE (2011) The restorative imperative: challenges, objectives and approaches to restoring naturalness in forests. Silva Fennica 45(5):843-863

Casselman CN, Fox TR, Burger JA, Jones AT, Galbraith JM (2006) Effects of silvicultural treatments on survival and growth of trees planted on reclaimed mine lands in the Appalachians. For Ecol Manage 223:403-414

Chaney WR, Pope PE, Byrnes WR (1995) Tree survival and growth on land reclaimed in accord with Public Law 95-87. J Environ Qual 24:630-634

Chen G, Weil R (2010) Penetration of cover crop roots through compacted soils. Plant Soil 331:31-43

Chodak M, Niklinska M (2010) Effect of texture and tree species on microbial properties of mine soils. App Soil Eco 46:268-275

Cohen-Fernandez A, Naeth M (2013) Increasing woody species diversity for sustainable limestone quarry reclamation in Canada. Sustainability 5:1340-1355

Cumulative Environmental Management Association (2006) Land capability classification system for forest ecosystems in the oil sands, 3rd edition. Alberta Environment. ISBN: 0-7785-4642-X

Cumulative Environmental Management Association (2009) Guidelines for reclamation to forest vegetation in the Athabasca oil sands regions. Alberta Environment ISBN: 978-0-7785-8826-9

Daniels WL, Amos DF (1985) Generating productive topsoil substitutes from hard rock overburden in southern Appalachians. Environ Geochem Health 7:8-15

Davis V, Franklin J, Zipper C, Angel P (2010) Planting hardwood tree seedlings on reclaimed mine land in Appalachia. US Office of Surface Mining, Appalachian Regional Reforestation Initiative, Forest Reclamation Advisory Number 7. http://arri.osmre.gov/FRA/Advisories/FRA_No.7_Feb.26.2010.pdf

Davis V, Burger J, Rathfon R, Zipper C, Miller C (2012) Selecting tree species for reforestation of Appalachian mined land. US Office of Surface Mining, Appalachian Regional Reforestation Initiative, Forest Reclamation Advisory Number 9. http://arri.osmre.gov/FRA/Advisories/FRA_No.9_ TreeSpeciesSelection.pdf

Devito K, Mendoza C, Qualizza C (2012) Conceptualizing water movement in the Boreal Plains. Implications for watershed reconstruction. Synthesis report prepared for the Canadian Oil Sands Network for Research and Development, Environmental and Reclamation Research Group, 164 pp

Dimitriu PA, Prescott CE, Quideau SA, Grayston SJ (2010) Impact of reclamation of surface-mined boreal forest soils on microbial community composition and function. Soil Biol Biochem 42:2289-2297

Emerson PJ, Skousen J, Ziemkiewicz P (2009) Survival and growth of native hardwoods in brown vs gray sandstone on a reclaimed surface mine in West Virginia. J Environ Qual 38:1821-1829

Eviner V, Hawkes C (2008) Embracing variability in the application of plant-soil interactions to the restoration of communities and ecosystems. Rest Ecol 16:713-728

Franklin JA, Zipper CE, Burger JA, Skousen JG, Jacobs DF (2012) Influence of herbaceous ground cover on forest restoration of eastern US coal surface mines. New Forest 43:905-924

French ME, Barton CD, Graves D, Angel PN, Hebard FV (2007) Evaluation of mine spoil suitability for the introduction of American chestnut hybrids in the Cumberland Plateau. In: Barnhisel RI (ed) 
Proceedings of the 2007 national meeting of the American Society of Mining and Reclamation. ASMR, Lexington, KY, pp 249-258

Frouz J (2013) Conclusions and practical implications. In: Frouz J (ed) Soil biota and ecosystem development in post mining sites. CRC Press, Bota Racon, pp 290-302

Frouz J, Kuráž V (2013) Soil fauna and soil physical properties. In: Frouz J (ed) Soil biota and ecosystem development in post mining sites. CRC Press, Bota Racon, pp 265-278

Frouz J, Keplin B, Pizl V, Tajovsky K, Stary J, Lukesova A, Novakova A, Balik V, Hanel L, Materna J, Duker C, Chalupsky J, Rusek J, Heinkele T (2001) Soil biota and upper soil layer development in two contrasting post-mining chronosequences. Ecol Eng 17:275-284

Frouz J, Pizl V, Cienciala E, Kalcik J (2009) Carbon storage in post-mining forest soil, the role of tree biomass and soil bioturbation. Biogeochemistry 94:111-121

Frouz J, Kalčík J, Velichová V (2011) Factors causing spatial heterogeneity in soil properties, plant cover, and soil fauna in a non-reclaimed post-mining site. Ecol Engineer 37:1910-1913

Frouz J, Elhottova D, Baldrian P, Chronakova A, Kristufek V (2013a) Soil microflora development in postmining sites. In: Frouz J (ed) Soil biota and ecosystem development in post mining sites. CRC Press, Boca Raton, pp 104-131

Frouz J, Jílková V, Cajthaml T, Pižl V, Tajovský K, Háněl L, Burešová A, Šimáčková H, Kolaříková K, Franklin J, Nawrot J, Groninger J, Stahl P (2013b) Soil biota in post-mining sites along a climatic gradient in the USA: simple communities in shortgrass prairie recover faster than complex communities in tallgrass prairie and forest. Soil Biol Biochem 67:212-225

Frouz J, Livečková M, Albrechtová J, Chroňáková A, Cajthaml T, Pižl V, Háněl L, Starý J, Baldrián P, Lhotáková Z, Šimáčková H, Cepáková S (2013c) Is the effect of trees on soil properties mediated by soil fauna? A case study from post-mining sites. Forest Ecol Manage 309:87-95

Frouz J, Pižl V, Tajovský K, Starý J, Holec M, Materna J (2013d) Soil macro- and mesofauna succession in post-mining sites and other disturbed areas. In: Frouz $\mathbf{J}$ (ed) Soil biota and ecosystem development in post mining sites. CRC Press, Bota Racon, pp 217-235

Fung M, Macyk T (2000) Reclamation of oil sands mining areas. In: Barnhisel R et al. (eds) Reclamation of drastically disturbed lands, 2nd ed. Agron. Monogr. 41. ASA, CSSA, and SSSA, Madison, WI, pp 755-774

Gardner JH, Bell DT (2007) Bauxite mining restoraiotn by Aloca World Alumina Australia in Western Australia: social, political, historical, and environmental contexts. Restor Ecol 15:S3-S10

González-Alday J, Marrs R, Martínez-Ruiz C (2008) The influence of aspect on the early growth dynamics of hydroseeded species in coal reclamation areas. Appl Veg Sci 11(3):405-412

Goodale CL, Apps M, Birdsey R, Field C, Heath L, Houghton R, Jenkins J, Kohlmaier G, Kurz W, Liu S, Nabuurs G, Nilsson S, Shvidenko A (2002) Forest carbon sinks in the northern hemisphere. Ecol Appl 12:891-899

Gorman J, Skousen J, Sencindiver J, Ziemkiewicz P (2001) Forest productivity and minesoil development under a white pine plantation versus natural vegetation after 30 years. Proceedings of 18th annual meeting, American Society for Surface Mining and Reclamation, 2-7 June, 2001. Albuquerque, NM, pp 103-111

Government of Alberta (2014) Environmental protection and enhancement act. Revised Statutes of Alberta 2000 Chapter E-12. Alberta Queen's Printer. http://environment.alberta.ca/01530.html. Accessed on 14 May 2014

Grant CD, Koch J (2007) Decommissioning Western Australia's first bauxite mine: co-evolving vegetation restoraiotn techniques and targets. Ecol Mgmt Restor 8:92-105

Grant CD, Ward SC, Morley SC (2007) Return of ecosystem function to restored bauxite mines in Western Australia. Restor Ecol 15:S94-S103

Greene D, Zasada J, Sirois L, Kneeshaw D, Morin H, Charron I, Simard M (1999) A review of the regeneration dynamics of North American boreal forest tree species. Can J For Res 29:824-839

Grman E, Bassett T, Brudvig L (2013) Confronting contingency in restoration: management and site history determine outcomes of assembling prairies, but site characteristics and landscape context have little effect. J Appl Ecol 50:1234-1243

Groninger J, Skousen J, Angel P, Barton C, Burger J, Zipper C (2007) Mine reclamation practices to enhance forest development through natural succession. US Office of Surface Mining, Appalachian Regional Reforestation Initiative, Forest Reclamation Advisory Number 5. http://arri.osmre.gov/FRA/ Advisories/FRA_No.5.pdf

Haering K, Daniels WL, Galbraith J (2004) Appalachian mine soil morphology and properties: effects of weathering and mining method. Soil Sci Soc Am J 68:1315-1325

Hahn AS, Quideau SA (2013) Long-term effects of organic amendments on the recovery of plant and soil microbial communities following disturbance in the Canadian boreal forest. Plant Soil 363:331-344 
Hall S, Barton C, Baskin C (2010) Topsoil seed bank of an oak hickory forest in eastern Kentucky as a restoration tool on surface mines. Rest Ecol 18:834-842

Harden J, O’Neill K, Trumbore S, Veldhuis H, Stocks B (1997) Moss and soil contributions to the annual net carbon flux of a maturing boreal forest. J Geophysical Res 102:28805-28816

Harrington C, McGrath J, Kraft J (1999) Propagating native species: experience at the Wind River Nursery. Western J Appl For 14:61-64

Haskell DE, Flaspohler DJ, Webster CR, Meyer MW (2012) Variation in soil temperature, moisture, and plant growth with the addition of downed woody material on lakeshore restoration sites. Rest Ecol 20:113-121

Hillel D, Talpaz H (1977) Simulation of soil-water dynamics in layered soils. Soil Sci 123:54-62

Hodačová D, Prach K (2003) Spoil heaps from brown coal mining: technical reclamation versus spontaneous revegetation. Rest Ecol 11:385-391

Holmes P (2001) Shrubland restoration following woody alien invasion and mining: effects of topsoil depth, seed source, and fertilizer addition. Rest Ecol 9:71-84

Hoomehr S, Schwartz J, Yoder D, Drumm E, Wright W (2014) Erodibility of low-compaction steep-sloped reclaimed surface mine lands in the southern Appalachian region, USA. Hydrol Process. doi:10.1001/ hyp. 10135

Hu Z (2014) Legislation, technology and practice of mine land reclamation. CRC Press, London

Huang MB, Zettl JD, Barbour SL, Elshorbagy A, Si BC (2013) The impact of soil moisture availability on forest growth indices for variably layered coarse-textured soils. Ecohydrology 6:214-227

Ingram LJ, Shuman GE, Stahl PD, Spackman LK (2005) Microbial respiration and organic carbon indicate nutrient cycling recovery in reclaimed soils. Soil Sci Soc Am J 69:1737-1745

Insam H, Domnsch K (1988) Relationship between soil organic carbon and microbial biomass on chronosequences of reclamation sites. Microbial Ecol 15:177-188

IUSS Working Group WRB (2006) World reference base for soil resources 2006. World Soil Resources Reports No. 103. FAO, Rome. 128 pp

Iverson L, Wali M (1982) Buried, viable seeds and their relation to revegetation after surface mining. J Range Manage 35:648-652

Jacobs D (2007) Toward development of silvical strategies for forest restoration of American chestnut using blight-resistant hybrids. Biol Conserv 137:497-506

Jacobs DF, Dalgleish HJ, Nelson CD (2013) A conceptual framework for restoration of threatened plants: the effective model of American chestnut (Castanea dentata) reintroduction. New Phytol 197:378-393

Jasper DA (2007) Beneficial soil microorganisms of the jarrah forest and their recovery in bauxite mine restoration in southwestern Australia. Restor Ecol 15:S74-S84

Johnson C, Skousen J (1995) Minesoil properties of 15 abandoned mine land sites in West Virginia. J Environ Qual 24:635-643

Kappes H, Clausius A, Topp W (2012) Historical small-scale surface structures as a model for post-mining land reclamation. Rest Ecol 20:322-330

Kirmer A, Baasch A, Tischew S (2012) Sowing of low and high diversity seed mixtures in ecological restoration of surface mined-land. Appl Veg Sci 15:198-207

Kishchuk BE, Quideau SA, Wang Y, Prescott C (2014) Long-term soil response to variable-retention harvesting in the EMEND (Ecosystem Management Emulating Natural Disturbance) experiment, northwestern Alberta. Can J Soil Sci 94:263-279

Koch JM (2007) Restoring a jarrah forest understorey vegetation after bauxite mining in Western Australia? Restor Ecol 15:S26-S39

Koch JM, Hobbs RJ (2007) Synthesis: is Aloca successfully restoring a jarrah forest ecosystem after bauxite mining in Western Australia? Restor Ecol 15:S137-S144

Koch J, Ward S, Grant C, Ainsworth G (1996) Effects of bauxite mine restoration operations on topsoil seed reserves in the Jarrah forest of Western Australia. Rest Ecol 4:368-376

Laganière J, Pare D, Bergeron Y, Chen H, Brassard B, Cavard X (2013) Stability of soil carbon stocks varies with forest composition in the Canadian boreal biome. Ecosystems 16:852-865

Landhäusser SM, Stadt KJ, Lieffers VJ (1996) Competition between Calamagrostis canadensis and three replacement species at different densities and times of seeding. J Appl Ecol 33:1517-1526

Landhäusser SM, Lieffers VJ, Chow P (2007) Impact of chipping residues and its leachate on the initiation and growth of aspen root suckers. Can J Soil Sci 87:361-367

Landhäusser S, Deshaies D, Lieffers V (2010) Disturbance facilitates rapid range expansion of aspen into higher elevations of the Rocky Mountains under a warming climate. J Biogeography 37:68-76

Landhäusser S, Pinno B, Lieffers V, Chow P (2012a) Partitioning of carbon allocation to reserves or growth determines future performance of aspen seedlings. For Ecol Manage 275:43-51 
Landhäusser S, Rodriguez-Alvarez J, Marenholtz E, Lieffers V (2012b) Effect of stock type characteristics and time of planting on field performance of aspen (Populus tremuloides Michx.) seedling on boreal reclamation sites. New Forest 43:679-693

Larney FJ, Angers DA (2012) The role of organic amendments in soil reclamation: a review. Can J Soil Sci 92:19-38

Lavelle P, Bignell D, Lepage M (1997) Soil function in a changing world: the role of invertebrate ecosystem engineers. Eur J Soil Biol 33:159-193

Lesica P, Allendorf F (1999) Ecological genetics and the restoration of plant communities: mix or match? Rest Ecol 7:42-50

Lilles EB, Purdy BG, Chang S, Macdonald SE (2010) Soil and groundwater characteristics of saline sites supporting boreal mixedwood forests in northern Alberta. Can J Soil Sci 90:1-14

Lilles E, Purdy B, Macdonald SE, Chang S (2012) Growth of aspen and white spruce on naturally saline sites in northern Alberta: implications for development of boreal forest vegetation on reclaimed saline soils. Can J Soil Sci 92:213-227

Littlefield T, Barton C, Arthur M, Coyne M (2013) Factors controlling carbon distribution on reforested minelands and regenerating clearcuts in Appalachia, USA. Sci Tot Env 465:240-247

Löf M, Dey D, Navarro R, Jacobs D (2012) Mechanical site preparation for forest restoration. New Forest 43:825-848

Macdonald SE, Quideau S, Landhäusser S (2012) Rebuilding boreal forest ecosystems after industrial disturbance. In: Vitt D, Bhattia J (eds) Restoration and reclamation of boreal ecosystems: attaining sustainable development. Cambridge University Press, London, pp 123-160

Macdonald SE, Snively AEK, Fair JM, Landhäusser SM (2015) Early trajectories of forest understory development on reclamation sites: influence of forest floor placement and a cover crop. Restor Ecol. doi:10.1111/rec.12217

Machulla G, Bruns M, Scow K (2005) Microbial properties of mine spoil materials in the initial stages of soil development. Soil Sci Soc Am J 69:1069-1077

Mackenzie D, Naeth M (2007) Assisted natural recovery using a forest soil propagule bank in the Athabasca oil sands. In: Adkins S, Ashmore S, Navie S (eds) Seeds: biology, development and ecology. CAB International. Cambridge, MA

Mackenzie DD, Naeth MA (2010) The role of the forest soil propagule bank in assisted natural recovery after oil sands mining. Rest Ecol 18:418-427

Mackenzie D, Quideau S (2012) Laboratory-based nitrogen mineralization and biogeochemistry of two soils used in oil sands reclamation. Can J Soil Sci 92:131-142

Majer JD, Brennan KEC, Moir ML (2007) Invertebrates and the restoration of a forest ecosystem: 30 years of research following bauxite mining in Western Australia. Restor Ecol 15:S104-S115

Martin PA, Newton AC, Bullock JM (2013) Carbon pools recover more quickly than plant biodiversity in tropical secondary forests. Proc R Soc B 280:20132236

Mays DA, Sistani KR, Soileau JM (2000) Lime and fertilizer needs for land reclamation. In: Barnhisel RI (ed) Reclamation of drastically disturbed lands, 2nd ed. Agron. Monogr. 41. ASA, CSSA, and SSSA, Madison, WI, pp 217-240

McConkey T, Bulmer C, Sanborn P (2012) Effectiveness of five soil reclamation and reforestation techniques on oil and gas well sites in northeastern British Columbia. Can J Soil Sci 92:165-177

Merilä P, Malmivaara-Lämsä M, Spetz P, Stark S, Vierikko K, Derome J, Fritze H (2010) Soil organic matter quality as a link between microbial community structure and vegetation composition along a successional gradient in a boreal forest. Appl Soil Ecol 46:259-267

Miller J, Barton C, Agouridis C, Fogel A, Dowdy T, Angel P (2012) Evaluating soil genesis and reforestation success on a surface coal mine in Appalachia. Soil Sci Soc Am J 76:950-960

Miyazaki T, Hasegawa S, Kasubuchi T (1993) Water flow in soils. Marcel Dekker, New York

Moreno-de Las Heras M, Nicolau J, Espigares T (2008) Vegetation succession in reclaimed coal mining slopes in a Mediterranean-dry environment. Ecol Engineer 34(2):168-178

Mummey D, Stahl PD, Buyer J (2002) Microbial biomarkers as an indicator of ecosystem recovery following surface mine reclamation. Appl Soil Ecol 21:251-259

Naeth MA, Archibald HA, Nemirsky CL, Leskiw LA, Brierley JA, Bock MD, VandenBygaart AJ, Chanasyk DS (2012) Proposed classification for human modified soils in Canada: anthroposolic order. Can J Soil Sci 92:7-18

Newman G, Redente E (2001) Long-term plant community development as influenced by revegetation techniques. J Range Manage 54:717-724

Nichols OG, Grant CD (2007) Vertebrate fauna recolonization of restored bauxite mines - key findings from almost 30 years of monitoring and research. Restor Ecol 15:S116-S126 
Norman MA, Koch JM, Grant CD, Morald TK, Ward SC (2006) Vegetation succession after bauxite mining in Western Australia. Rest Ecol 14:278-288

Norris CE, Quideau SA, Bhatti JS, Wasyslishen RE, MacKenzie MD (2009) Influence of fire and harvest on soil organic carbon in jack pine sites. Can J For Res 39:642-654

Oil Sands Vegetation Reclamation Committee (OSVRC) (1998) Guidelines for reclamation to forest vegetation in the Athabasca oil sands region. Fort McMurray, Alberta, ISBN 0-7785-041105

Oliet J, Jacobs D (2012) Restoring forests: advances in techniques and theory. New Forest 43:535-541

Palumbo A, Amonette J, Fisher L, Wullshleger S, Daniels W (2004) Prospects for enhancing carbon sequestration and reclamation of degraded lands with fossil-fuel combustion by-products. Adv Env Res 8:425-438

Paré D, Bergeron Y, Camire C (1993) Changes in the forest floor of Canadian Southern Boreal forest after disturbance. J Veg Sci 4:811-818

Parrotta JA, Knowles OH, Wunderle JM Jr (1997) Development of floristic diversity in 10-year-old restoration forests on a bauxite mined site in Amazonia. For Ecol Mgmt 99:21-42

Pinno BD, Landhäusser SM, MacKenzie MD, Quideau SA, Chow PS (2012) Trembling aspen seedling establishment, growth, and response to fertilization on contrasting soils. Can J Soil Sci 92:143-151

Pinno BD, Landhäusser SM, Chow PS, Quideau SA, MacKenzie MD (2014) Nutrient uptake and growth of fireweed (Chamerion angustifolium) on reclamation soils. Can J For Res 44:1-7

Plass WT (1982) The impact of surface mining on the commercial forests of the United States. In: Kolar CA Ashby WC (eds) Post-mining productivity with trees. March 31-April 2, 1982, Southern Illinois University, Carbondale, IL, pp 1-7

Ponge JF (2003) Humus form in terrestrial ecosystem: a framework to biodiversity. Soil Biol Biochem 35:935-945

Poscente M, Charette T (2012) Criteria and indicators framework for oil sands mine reclamation certification. Cumulative Environmental Management Association. http://cemaonline.ca/index.php/ administration/cat_view/2-communications/18-rwg-recommendations

Potter HS, Weitzman S, Trimble GR (1955) Reforestation of stripped-mined lands. West Virginia Agriculture and Forestry Experiment Station Mimeograph Circular 55. West Virginia University, Morgantown

Powter C, Chymko C, Dinwoodie G, Howat D, Janz A, Puhlmann R, Richens T, Watson D, Sinton H, Ball K, Etmanski A, Patterson B, Brocke L, Dyer R (2012) Regulatory history of Alberta's industrial land conservation and reclamation program. Can J Soil Sci 92:39-51

Prach K, Bartha S, Joyce C, Pysek P, Van Diggelen R, Wiegleb G (2001) The role of spontaneous vegetation succession in ecosystem restoration: a perspective. Appl Veg Sci 4:111-114

Prescott C, Maynard D, Laiho R (2000) Humus in northern forests: friend or foe? For Ecol Manage 133:23-36

Purdy BG, Macdonald SE, Lieffers VJ (2005) Naturally saline boreal communities as models for reclamation of saline oil-sand tailings. Rest Ecol 13:667-677

Putwain P, Gillham D (1990) The significance of the dormant viable seed bank in the restoration of heathlands. Biol Conserv 52:1-16

Putz F, Canham C (1992) Mechanisms of arrested succession in shrublands: root and shoot competition between shrubs and tree seedlings. For Ecol Manage 49:267-275

Quideau SA, Norris CE, Soucémarianadin LN, Wasylishen RE (2013a) Forest ecology and soils. eMag Res 2:597-608. doi:10.1002/9780470034590.emrstm1339

Quideau SA, Swallow MJB, Prescott CE, Grayston SJ, Oh SW (2013b) Comparing soil biogeochemical processes in novel and natural boreal forest ecosystems. Biogeosciences 10:5651-5661

Rana S, Stahl P, Ingram L, Wick A (2007) Soil microbial community composition in reclaimed soil under different vegetation in Wyoming minelands. 30 years of SMCRA and beyond. In: Barnhisel R (ed) Proceedings American Society Mining and Reclamation, Gillette, WY. ASMR, Lexington, KY

Rodrigue JA, Burger JA (2004) Forest soil productivity of mined land in the Midwestern and eastern coalfield regions. Soil Sci Soc Am J 68:833-844

Rokich D, Dixon K, Sivasithamparam K, Meney K (2000) Topsoil handling and storage effects on woodland restoration in Western Australia. Rest Ecol 8:196-208

Rowland SM, Prescott CE, Grayston SJ, Quideau SA, Bradfield GE (2009) Recreating a functioning forest soil in reclaimed oil sands in northern Alberta: an approach for measuring success in ecological restoration. J Environ Qual 38:1580-1590

Salifu KF, Jacobs DF (2006) Characterizing fertility targets and multi-element interactions in nursery culture of Quercus rubra seedlings. Annals For Sci 63:231-237

Salifu K, Jacobs D, Birge Z (2009) Nursery nitrogen loading improves field performance of bareroot oak seedlings planted on abandoned mine lands. Rest Ecol 17:339-349 
Schimmel J, Granstrom A (1996) Fire severity and vegetation response in the Boreal Swedish Forest. Ecol $77: 1436-1450$

Schott KM, Pinno BD, Landhäusser SM (2013) Premature shoot growth termination allows nutrient loading of seedlings with an indeterminate growth strategy. New Forest 44:635-647

Schott KM, Karst J, Landhäusser SM (2014) The role of microsite conditions in restoring trembling aspen (Populus tremuloides Michx) from seed. Restor Ecol 22:292-295

Sencindiver JC, Ammons JT (2000) Minesoil genesis and classification. In: Barnhisel R et al. (ed) Reclamation of drastically disturbed lands, 2nd ed. Agron. Monogr. 41, ASA, CSSA, and SSSA, Madison, WI, pp 595-613

Si B, Dyck M, Parkin GW (2011) Flow and transport in layered soils. Can J Soil Sci 91:127-132

Skousen J, Venable C (2008) Establishing native plants on newly-constructed and older-reclaimed sites along West Virginia highways. Land Degrad Develop 19:388-396

Skousen J, Zipper C (2010) Powell River Project-Revegetation species and practices. Virginia Cooperative Extension 460-122, Blacksburg, VA. http://pubs.ext.vt.edu/460/460-122/460-122.html

Skousen J, Zipper C (2014) Post-mining policies and practices in the Eastern USA coal region. Intl J Coal Sci Techn 1:135-151

Skousen J, Johnson C, Garbutt K (1994) Natural revegetation of 15 abandoned mine land sites in West Virginia. J Environ Qual 23:1224-1230

Skousen J, Ziemkiewicz P, Venable C (2006) Tree recruitment and growth on 20-yr-old, unreclaimed surface mined lands in West Virginia. Intl J Mining Reclam Environ 20:142-154

Skousen J, Gorman J, Pena-Yewtukhiw E, King J, Stewart J, Emerson P, DeLong C (2009) Hardwood tree survival in heavy ground cover on reclaimed land in West Virginia: mowing and ripping effects. J Environ Qual 38:1400-1409

Skousen J, Zipper C, Burger J, Barton C, Angel P (2011) Selecting materials for mine soil construction when establishing forests on Appalachian mine sites. US Office of Surface Mining, Appalachian Regional Reforestation Initiative, Forest Reclamation Advisory Number 8, July 2011. http://arri.osmre.gov/

Smith RM, Sobek AA (1978) Physical and chemical properties of overburdens, spoils, wastes, and new soils. In: Schaller F, Sutton P (eds) Reclamation of drastically disturbed lands, 1st ed. ASA,CSSA, and SSSA, Madison, WI, pp 149-172

Smreciu A, Gould K (2013) Oil sands vegetation cooperative: a coordinated effort to harvest seeds for reclamation in northeastern Alberta. Can Recl 2:16-17

Sobek AA, Skousen JG, Fisher SE (2000) Chemical and physical properties of overburdens and minesoils. In: Barnhisel RI (ed) Reclamation of drastically disturbed lands, 2nd ed. Agron. Monogr. 41. ASA, CSSA, and SSSA, Madison, WI, pp 77-104

Sorenson PT, Quideau SA, MacKenzie MD, Landhäusser SM, Oh SW (2011) Forest floor development and biochemical properties in reconstructed boreal forest soils. Appl Soil Ecol 49:139-147

Stormont JC (1996) The effectiveness of two capillary barriers on a $10 \%$ slope. J Geotech Geol Eng $14: 243-267$

Sweigard R, Burger J, Zipper C, Skousen J, Barton C, Angel P (2007) Low compaction grading to enhance reforestation success on coal surface mines. US Office of Surface Mining, Appalachian Regional Reforestation Initiative, Forest Reclamation Advisory Number 3. http://arri.osmre.gov/FRA/ Advisories/FRA_No.3.pdf

Sylvia D, Fuhmann J, Hartel P, Zuberer D (2005) Principles and applications of soil microbiology. Pearson Inc, Upper Saddle River

Tacey W, Glossop B (1980) Assessment of topsoil handling techniques for rehabilitation of sites mined for bauxite within the Jarrah forest of Western Australia. J Appl Ecol 17:195-201

Torbert JL, Burger JA (2000) Forest land reclamation. In: Barnhisel RI (ed) Reclamation of drastically disturbed lands, 2nd ed. Agron. Monogr. 41. ASA, CSSA, and SSSA, Madison, WI, pp 371-398

Torbert JL, Burger JA, Daniels WL (1990) Pine growth variation associated with overburden rock type on a reclaimed surface mine in Virginia. J Environ Qual 19:88-92

Toy T, Black J (2000) Topographic reconstruction: the theory and practice. In: Barnhisel RI et al. (ed) Reclamation of drastically disturbed lands, 2nd ed. Agron. Monogr. 41. ASA, CSSA, and SSSA, Madison, WI, pp 41-75

Toy TJ, Chuse WR (2005) Topographic reconstruction: a geomorphic approach. Ecol Eng 24:29-35

Tropek R, Hejda M, Kadlec T, Spitzer L (2013) Local and landscape factors affecting communities of plants and diurnal Lepidoptera in black coal spoil heaps: implications for restoration management. Ecol Eng $57: 252-260$

Tryon EH (1952) Forest cover for spoil banks. West Virginia Agriculture and Forest Experiment Station Bulletin 357. West Virginia University, Morgantown, WV 
Turcotte I, Quideau S, Oh S (2009) Organic matter quality in reclaimed boreal forest soils following oil sands mining. Org Geochem 40:510-519

Vetterlein D, Hüttl RF (1999) Can applied organic matter fulfil similar functions as soil organic matter? Risk-benefit analysis for organic matter application as a potential strategy for rehabilitation of disturbed ecosystems. Plant Soil 213:1-10

Villar-Salvador P, Puértolas J, Cuesta B, Peñuelas JL, Uscola M, Heredia-Guerrero N, Rey Benayas JM (2012) Increase in size and nitrogen concentration enhances seedling survival in Mediterranean plantations. Insights from an ecophysiological conceptual model of plant survival. New Forest 43:755-770

Vindušková O, Frouz J (2013) Soil carbon accumulation after open-cast coal and oil shale mining in Northern Hemisphere: a quantitative review. Environ Earth Sci 69:1685-1698

Vinge T, Pyper M (2012) Managing woody debris on industrial sites: Meeting economic, ecological and forest health goals through a collaborative approach, $47 \mathrm{pp}$. http://issuu.com/ales.rr.issuu/docs/ woodymaterialsreview

Vogt K, Vogt D, Brown S, Tilley J, Edmonds R, Silver W, Siccama T (1995) Dynamics of forest floor and soil organic matter accumulation in boreal, temperate, and tropical forests. Adv Soil Sci 62:159-178

Wilson-Kokes L, Emerson P, DeLong C, Thomas C, Skousen J (2013a) Hardwood tree growth after eight years on brown and gray mine soils in West Virginia. J Env Qual 42:1353-1362

Wilson-Kokes L, Emerson P, DeLong C, Thomas C, O’Dell K, Skousen J (2013b) Hardwood tree growth on amended mine soils in West Virginia. J Env Qual 42:1363-1371

Wolken JM, Landhäusser SM, Lieffers VJ, Dyck M (2010) Differences in initial root development and soil conditions affect establishment of trembling aspen and balsam poplar seedlings. Botany 88:275-285

Wong M (2003) Ecological restoration of mine degraded soils, with emphasis on metal contaminated soils. Chemosphere 50(6):775-780

World Resources Institute (2014) Atlas of forest landscape restoration opportunities. http://www.wri.org/ applications/maps/flr-atlas/\# Accessed 23 June 2014

Zeleznik J, Skousen J (1996) Survival of three tree species on old reclaimed surface mines in Ohio. J Environ Qual 25:1429-1435

Zettl JD, Barbour SL, Huang M, Si BC, Leskiw LA (2011) Influence of textural layering on field capacity of coarse soils. Can J Soil Sci 91:133-147

Zhang Z, Shu W, Lan C, Wong M (2001) Soil seed bank as an input of seed source in revegetation of lead/ zinc mine tailings. Rest Ecol 9:378-385

Zipper C (2000) Coal mine reclamation, acid mine drainage, and the Clean Water Act. In: Barnhisel RI (ed) Reclamation of drastically disturbed lands, 2nd ed. Agron. Monogr. 41. ASA, CSSA, and SSSA, Madison, WI, pp 169-191

Zipper CE, Burger JA, McGrath JM, Rodrigue JA, Holtzman GI (2011a) Forest restoration potentials of coal mined lands in the eastern United States. J Environ Qual 40:1567-1577

Zipper CE, Burger JA, Skousen JG, Angel PN, Barton CD, Davis V, Franklin JA (2011b) Restoring forests and associated ecosystem services on Appalachian coal surface mines. Environ Manage 47:751-765

Zipper C, Burger J, Barton C, Skousen J (2013) Rebuilding soils for forest restoration on Appalachian mined lands. Soil Sci Soc Am J 77:337-349 